\title{
Geologia

\section{Geologia e Geocronologia do Maciço Alcalino Máfico-Ultramáfico Ponte Nova (SP-MG)}

\section{G eology and Geochronology of Ponte N ova Mafic-Ultramafic Massif (SP-M G)}

\author{
Rogério Guitarrari Azzone (rgazzone@usp.br), Excelso Ruberti (exrubert@usp.br), \\ Gaston Eduardo Enrich Rojas (gastonenrich@usp.br), Celso de Barros Gomes (cgomes@usp.br) \\ Departamento de Mineralogia e Geotectônica - Instituto de G eociências - USP
}

R. do Lago 562, CEP 05508-080, São Paulo, SP, BR

Recebido em 07 de outubro de 2008; aceito em 23 de março de 2009

\begin{abstract}
RESUMO
O maciço alcalino máfico-ultramáfico Ponte Nova, localizado no setor norte da Província Serra do Mar, junto à porção oriental da Serra da Mantiqueira, na região Sudeste do Brasil, encontra-se encaixado em granitoides e gnaisses migmatíticos Pré-Cambrianos. O maciço apresenta duas áreas distintas de exposição, estando ambas separadas por rochas do embasamento: uma maior $\left(\sim 5,5 \mathrm{~km}^{2}\right)$, de forma elíptica e com grande variedade de litotipos; outra menor $\left(\sim 1 \mathrm{~km}^{2}\right)$, de forma irregular e petrograficamente menos complexa, e situada a sul da primeira. É predominantemente composto por uma associação gabroide alcalina, gerada por sucessivos pulsos magmáticos. As rochas mais abundantes são cumulatos máficos e ultramáficos (e.g., olivina clinopiroxenitos e melagabros com olivina) presentes nos níveis inferiores do maciço, ao lado de rochas gábricas e monzogábricas porfiríticas, equigranulares e bandadas nos níveis superiores, todos representativos da evolução magmática dos principais pulsos. Um corpo de brecha magmática e uma suíte de diques (lamprófiros a tefrifonólitos) interceptam todas as rochas intrusivas. Análises geocronológicas por K/Ar para diferentes rochas indicam uma idade média de 87,6 Ma (Cretáceo Superior), que é similar às obtidas para as demais ocorrências do setor norte da referida província. A incompatibilidade das idades torna difícil sustentar a hipótese de sua associação genética com a pluma mantélica de Trindade.
\end{abstract}

Palavras-chave: Magmatismo alcalino; Província Serra do Mar; Cumulatos máfico-ultramáficos; Geocronologia.

\begin{abstract}
The Ponte Nova alkaline mafic-ultramafic massif lies in the northern sector of the Serra do Mar Province, close to the eastern part of the Mantiqueira mountain range, SE Brazil. The massif is exposed in two different areas separated by basement rocks: the larger $\left(\sim 5.5 \mathrm{~km}^{2}\right)$ is elliptical in shape and has a wide variety of rock types; the smaller $\left(\sim 1 \mathrm{~km}^{2}\right)$ is irregular, petrographically less complex, and occurs south of the former. It is mainly composed of an alkaline gabbro association generated by successive magmatic pulses. The more abundant rocks are melagabbros and ultramafic cumulates (e.g., olivine clinopyroxenites and olivine-bearing melagabbros) found in the lower parts of the massif, together with porphyritic, equigranular and banded gabbros and monzogabbros in the upper partions. A magmatic breccia and a suite of dykes (lamprophyres to tephriphonolites) cut the intrusion. K/Ar geochronological data for the different rock types yielded an average Late Cretaceous age of 87.6 Ma which is comparable to the age of other alkaline intrusions present in the northern sector of the referred province. The difference in ages makes it difficult to sustain the hypothesis of a genetical association with the Trindade mantle plume.
\end{abstract}

Keywords: Alkaline magmatism; Serra do Mar Province; Mafic-Ultramafic cumulates; Geochronology. 


\section{INTRODUÇÃO}

O maciço alcalino máfico-ultramáfico Ponte Nova ( $22^{\circ} 47^{\prime} \mathrm{S}, 45^{\circ} 45^{\prime} \mathrm{W}$ ) é parte do extenso magmatismo alcalino-carbonatítico continental Meso-Cenozoico que ocorre nas regiões central e sudeste da Plataforma SulAmericana.

As características mais notáveis dessas associações são, segundo Morbidelli et al. (1995) e Gomes e CominChiaramonti (2005): o predomínio das ocorrências intrusivas, a abundância de litotipos evoluídos (especialmente nefelina sienitos e sienitos), e a presença de material cumulático (frequentemente clinopiroxenitos e membros da série ijolítica, com dunitos em menor proporção), este volumetricamente mais restrito. O maciço Ponte Nova representa um exemplo típico da última situação, sendo formado eminentemente por rochas cumuláticas de tendência alcalina.

O maciço situa-se na zona limítrofe entre os estados de São Paulo e Minas Gerais, mais precisamente entre as localidades de Sapucaí-Mirim (MG) e Santo Antônio do Pinhal (SP), e não muito distante da cidade de Campos do Jordão (SP). As rodovias estaduais SP-50 (Monteiro Lobato) e SP-42 (Vereador Júlio da Silva) atravessam toda a sua extensão N-S.

$\mathrm{Na}$ literatura, a primeira menção a rochas alcalinas na região de Campos do Jordão remonta a Freitas (1947), em artigo que tratou mais especificamente da geologia e petrologia da Ilha de São Sebastião.

Durante a década de 70, diversos trabalhos regionais registraram a ocorrência dessas rochas na área acima, principalmente na forma de diques (e.g., Miniolli, 1971; Melcher e Melcher, 1972). Contudo, uma descrição geológica e petrográfica do maciço somente veio a ser conduzida por Alves (1978), que o denominou "corpo gabroide de Sapucaí Mirim". Posteriormente, a ocorrência passou a ser referida na literatura como Ponte Nova (cf. Cavalcante et al., 1979), nome adotado nos trabalhos que se seguiram (e.g., Almeida, 1983; Garda e Chieragatti, 1997; Thompson et al., 1998).

Outros artigos que se ocuparam da ocorrência, fornecendo dados de natureza geológica, geoquímica e geocronológica, porém, sempre com um enfoque mais regional, foram os de Hama et al. (1979) e Alves, Ruberti e Vlach (1992). Cumpre ressaltar ser o maciço Ponte Nova a única ocorrência alcalina do setor norte da Província Serra do Mar com predomínio acentuado de rochas máficas e ultramáficas.

O objetivo deste trabalho é a apresentação das peculiaridades geológicas e petrográficas e de novos dados geocronológicos K-Ar para o maciço, bem como de um modelo de sua evolução geológica.

\section{CONTEXTO GEOLÓGICO}

\section{Regional}

A ativação tectônico-magmática meso-cenozoica na Plataforma Sul-Americana teve como resultado um magmatismo intenso e variado, caracterizado pela reativação de antigos falhamentos, surgimento de blocos de falha, soerguimento de arcos, abatimento de bacias costeiras e acentuada subsidência da Bacia do Paraná (Almeida, 1983, 1986). Na sua porção sudeste, esse magmatismo manifesta-se de forma extensa por vulcanismo basáltico de caráter toleítico, com seus derivados ácidos, e também por enxames de diques de diabásio expostos junto às bordas daquela bacia. Esses derrames estenderam-se até a área que viria a ser ocupada pela Bacia de Santos. Já de ocorrência mais restrita, na forma de stocks, plugs, diques e pipes, é a manifestação do magmatismo alcalino-carbonatítico, condicionado a zonas de falhas, arcos e flexuras reativadas localizadas nas bordas dessas bacias.

A Província Serra do Mar (Figura 1), como definida por Ulbrich e Gomes (1981) e Almeida (1983), reúne as ocorrências alcalinas do Cretáceo Superior ao Paleoceno Inferior, que se situam na região litorânea dos estados de São Paulo e Rio de Janeiro, bem como se estendem para o interior do continente até a Serra da Mantiqueira. Elas encontram-se encaixadas em rochas neoproterozoicas da Faixa Ribeira (750 - 450 Ma; Almeida et al., 1973; Machado et al., 1996; Heilbron et al., 2004), representadas dominantemente por rochas ígneas e metamórficas de composição granítica.

Riccomini, Velázquez e Gomes (2005), com base em novos dados geológicos, geocronológicos, estruturais e geofísicos, revisaram o modelo classificatório de Almeida (1983) e propuseram a subdivisão daquela província em duas outras:

a. Província Serra do Mar, englobando tão só as ocorrências do Cretáceo Superior, além de desenvolvida na porção continental na borda oeste da Bacia de Santos;

b. Província do Lineamento Magmático Cabo Frio, com pelo menos duas fases de magmatismo alcalino, do Cretáceo Superior ao Paleógeno, reunindo as ocorrências dispostas ao longo do citado lineamento.

A Província Serra do Mar segundo Riccomini, Velázquez e Gomes (2005) é, contudo, mais abrangente do ponto de vista geográfico, envolvendo as rochas alcalinas do Cretáceo Superior da região do Arco de Ponta Grossa, anteriormente incluídas em província homônima, e de Lages, estas antes relacionadas à Província Santa Catarina (cf. Almeida, 1983). Dessa forma, a Província Serra do Mar por 
eles proposta é dividida em três setores (norte, central e sul), que correspondem a áreas de importantes soerguimentos cenozoicos ao longo da região costeira onshore do Sudeste do Brasil.

O setor norte reúne as intrusões alcalinas das ilhas costeiras (São Sebastião, Monte de Trigo, Vitória e Búzios) e o maciço Ponte Nova, na região da Serra da Mantiqueira. Além disso, inclui os diques alcalinos máficos e félsicos que ocorrem nessas áreas.

Petrograficamente, segundo Ulbrich e Gomes (1981) e Almeida (1983), as intrusões alcalinas desse segmento possuem caráter predominantemente félsico nas ilhas costeiras (nefelina sienitos, sienitos, álcali sienitos, fonólitos e traquitos), embora rochas máficas ocorram localmente, na forma de diques ou pequenos stocks, como os corpos gabroides cumuláticos da Ilha de São Sebastião (Lima, 2001; Augusto, 2003) e da ilha Monte de Trigo (Enrich, Ruberti, Gomes, 2009). Por sua vez, o maciço Ponte Nova apresenta caráter máfico-ultramáfico e área aflorante superior a das ocorrências máficas e mesmo a algumas das ocorrências plutônicas de caráter félsico encontradas nas adjacências.

\section{Local}

O maciço Ponte Nova, situado na porção oriental da Serra da Mantiqueira, encontra-se encaixado em diferentes unidades pré-cambrianas, numa região de contato entre os domínios das faixas móveis neoproterozoicas Ribeira e Brasília.

Segundo Cavalcante et al. (1979), as relações de contato na sua porção setentrional se dão com a Associação Paraíba do Sul em seu Complexo Piquete, representada localmente por rochas migmatíticas e gnáissicas, quartzitos e metabasitos. No restante, com rochas da Associação Barbacena em seu Complexo Paraisópolis, tendo granitos e granitoides porfiroides metassomáticos, além de migma-
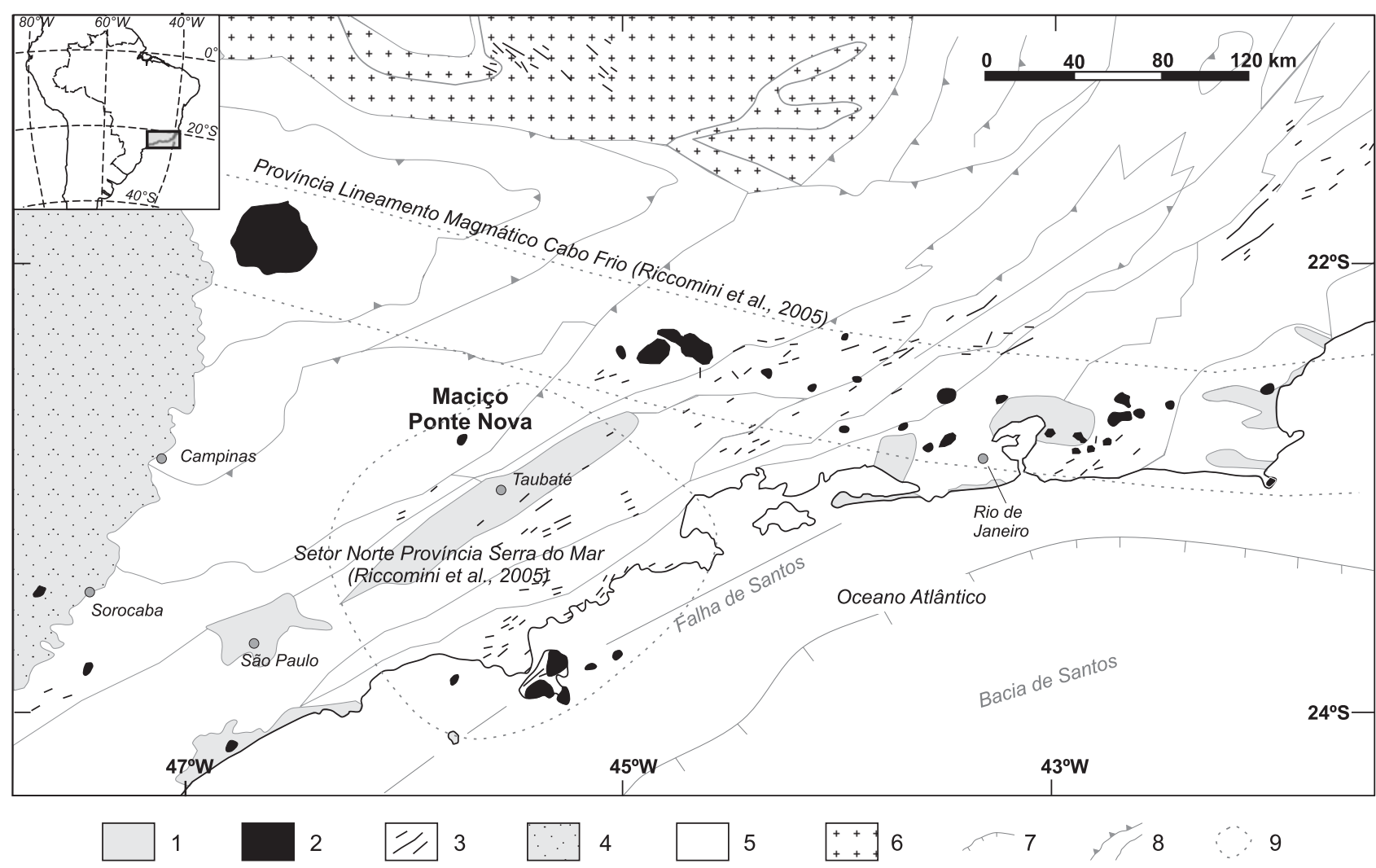

8

9

Figura 1. Distribuição dos corpos alcalinos na região do Vale do Paraíba e faixa litorânea dos estados de São Paulo e Rio de Janeiro (Província Serra do Mar de Almeida, 1983), com as principais unidades tectônicas do embasamento. Apresenta-se também a nova subdivisão das províncias alcalinas proposta por Riccomini, Velázquez e Gomes (2005). 1. Bacias de rifte (Cenozoico). 2. O corrências alcalinas (Meso-Cenozoico). 3 e 4. Bacia do Paraná (Paleozoico), respectivamente, diques e lavas. 5. O rógenos Brasília e Ribeira (Pré-Cambriano). 6. Craton do São Francisco (Pré-Cambriano). 7. Limites da Bacia de Santos. 8. Principais estruturas (falhamentos) do embasamento (Pré-Cambriano). 9. Nova subdivisão províncias alcalinas da região. Compilado de Almeida (1983), Heilbron et al. (2004) e Riccomini, Velázquez e Gomes (2005). 
titos bandados e granito-gnaisses, como principais tipos litológicos. Essas últimas rochas são também interpretadas como sendo uma unidade granitoide sintectônica de fácies Cantareira (Almeida et al., 1981), enquanto Santoro (1998) define esse corpo granítico como suíte Serra Preta. Todas as rochas encaixantes têm contatos entre si delimitados por falhas e parecem representar conjuntos policíclicos submetidos a estágios tectono-termais bastante ativos. Em termos geoquímicos, os granitos da suíte Serra Preta constituem uma sequência cogenética cálcio-alcalina monzogranítica de alto potássio, meta a peraluminosa, gerada em ambiente compressivo (Santoro, 1998).

\section{GEOLOGIA E PETROGRAFIA}

O maciço Ponte Nova, de caráter dominantemente cumulático, ocupa a morraria drenada pelos rios Preto-Grande e Sapucaí-Mirim, alcançando altitudes de 900 a $1.200 \mathrm{~m}$. Ele apresenta duas áreas de exposição, com a principal $\left(\sim 5,5 \mathrm{~km}^{2}\right)$ exibindo forma elíptica e maior variedade de litotipos. $\mathrm{O}$ eixo maior tem direção aproximada $\mathrm{N}-\mathrm{S}$ e $4 \mathrm{~km}$ de extensão, enquanto o menor, uma largura máxima de $3 \mathrm{~km}$. Os seus contornos estão condicionados a lineamentos estruturais ou a feições geomorfológicas. A segunda área de exposição $\left(\sim 1 \mathrm{~km}^{2}\right)$, a sul da anterior, possui contorno ligeiramente ovalado, com o eixo maior orientado para NE-SW, e medindo cerca de $1,5 \mathrm{~km}$. As duas áreas estão separadas por afloramentos do embasamento granítico Pré-Cambriano regional.

A Figura 2 mostra o mapa geológico do maciço, juntamente com a localização de diques e algumas feições estruturais principais. Os contatos com as rochas encaixantes são inferidos por aspectos geomorfológicos e natureza dos afloramentos. Na maioria das vezes, as rochas encaixantes mais próximas apresentam declividades e altitudes mais acentuadas que as rochas do maciço. Em alguns casos, encontram-se também mistura de blocos em zonas de drenagem e matacões do embasamento nas cristas de morros, que têm rochas gábricas na sua base. Estas ocorrências, que também foram mapeadas, poderiam indicar a presença de roof pendants na câmara magmática.

A maioria dos afloramentos ocorre sob a forma de blocos, muitos não in situ, ainda que próximos de seus lugares de origem. Em alguns locais, os blocos e matacões estão in situ e, juntamente com pedreiras, fornecem elementos que ajudam na construção de um mapa faciológico da área (Figuras $3 \mathrm{~A}$ e $3 \mathrm{~B}$ ). Os contatos entre as diferentes fácies petrográficas são em geral inferidos, levando-se em consideração os lineamentos estruturais definidos por estudos de sensoriamento remoto. A maior parte desses lineamentos representa as principais linhas de drenagem do maciço, que devem corresponder a falhamentos sin a pós-magmá- ticos. Por vezes, esses controles geológicos e geomorfológicos possibilitam a caracterização de pulsos magmáticos isolados, porém, em algumas áreas esses elementos não são tão diagnósticos.

As rochas cumuláticas melanocráticas e ultramáficas ocorrem associadas, sendo predominantes no maciço. $\mathrm{Na}$ tentativa de reconstrução da sua possível estratigrafia, notou-se que elas têm a tendência geral de se mostrarem mais félsicas e mais finas com a elevação topográfica. Essas características são compatíveis com as das principais intrusões acamadadas descritas na literatura (e.g., Skaergaard, Rhum, Kokklen), que contêm rochas ultramáficas a melanocráticas em suas porções basais. É sob a luz da geologia desses complexos que o mapa geológico foi construído. A Tabela 1 e a Figura 4 apresentam as composições mineralógicas modais dos principais litotipos associados às diferentes fácies descritas a seguir.

\section{Fácies cumulatos ultramáficos - UMFc}

$\mathrm{Na}$ região intermediária, porções centro-norte e nordeste do maciço, ocorrem olivina clinopiroxenitos a clinopiroxenitos com olivina (Figuras 5A e 5B). Essas rochas exibem estrutura maciça e textura cumulática, inequigranular média a grossa (a segunda dominante), com os cristais maiores atingindo tamanho de até $1,5 \mathrm{~cm}$. O clinopiroxênio (opticamente variável entre diopsídio e titanoaugita) é a principal fase cumulus, com olivina subordinada. Sobrecrescimentos com variação composicional dos cristais cumuláticos, como sugerido por estruturas zonadas, preenchem grande parte dos seus interstícios. Em algumas amostras estão também presentes cristais cumuláticos de Ti-magnetita e ilmenita em proporções limitadas e inferiores às de outras fases cumuláticas. Plagioclásio é a única fase félsica identificada. Na porção NE da área aparecem também rochas texturalmente muito similares, porém, trazendo elevada concentração relativa de fases máficas hidratadas intersticiais, que substituem os cristais de clinopiroxênio, conforme indicado por texturas de corrosão. Elas são classificadas como olivina-kaersutita clinopiroxenitos a biotita-kaersutita clinopiroxenitos com olivina (Figura 5B) e chegam a conter na moda até $28 \%$ de anfibólio e biotita.

\section{Fácies cumulatos melagábricos - MLGc}

Estas rochas são as mais abundantes do maciço, aflorando principalmente na sua porção central. Elas estão representadas por olivina melagabros a melagabros com olivina $(67<\mathrm{M}<86$; Figuras $3 \mathrm{C}, 3 \mathrm{D}$ e $5 \mathrm{C})$ e mostram textura inequigranular fina a grossa, com predomínio da granulação média. Os cristais maiores de clinopiroxênio e olivi- 

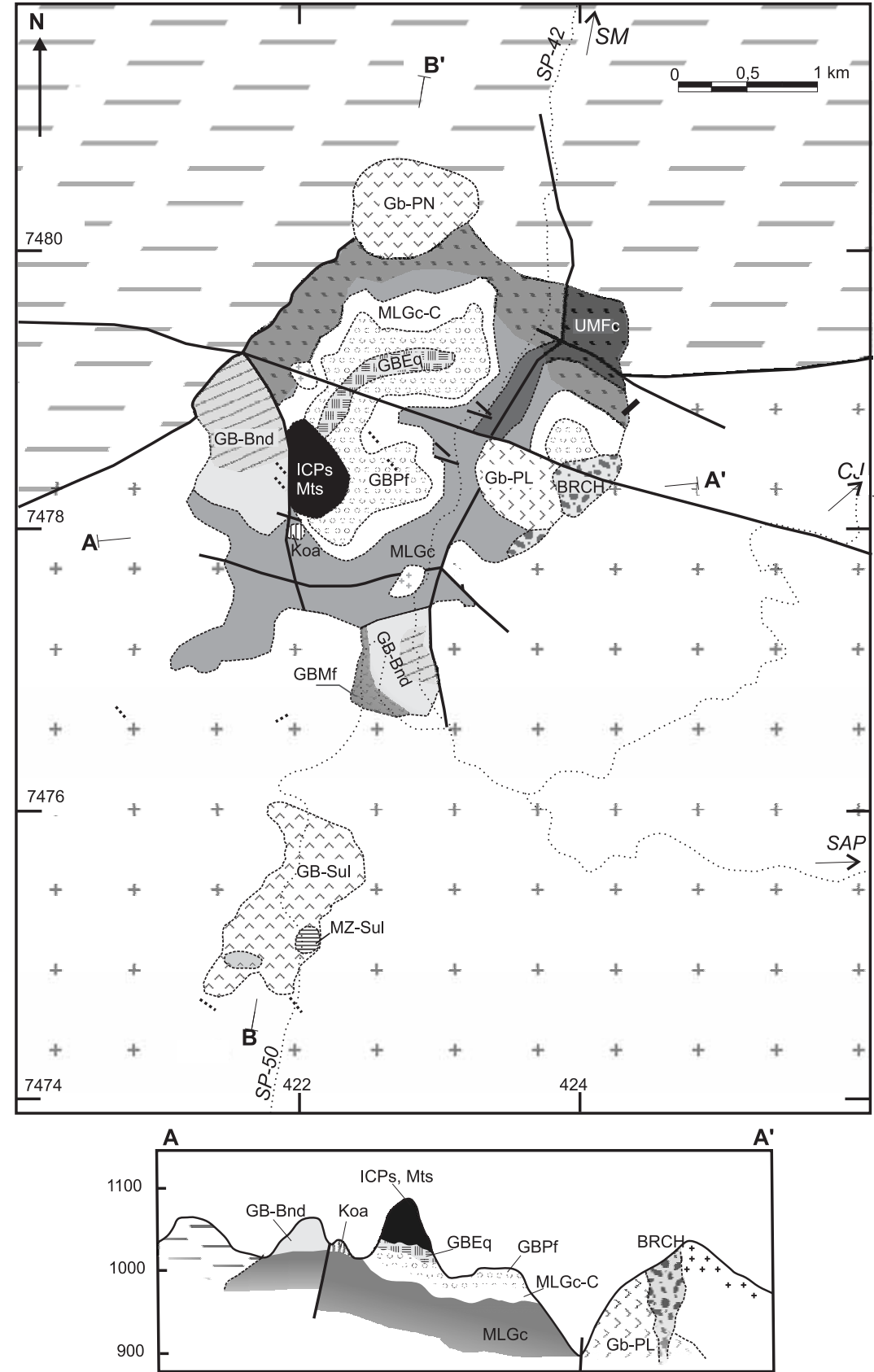

Legenda

Rochas Mesozoicas/Cenozoicas

1. Diques in situ (linha cheia) e afloramentos com blocos de prováveis diques (linha pontilhada)

BRCH - brecha magmática

? Gb-PL - nefelina monzodioritos a monzodioritos com nefelina

Gb-PN - olivina melamonzodioritos a melamonzodioritos com olivina

GB-Sul - Área satélite a sul. a sul. b. melamonzodioritos com nefelina c. MZ-Sul - monzonitos com nefelina

\section{GB-Bnd}

a. melamonzonitos com nefelina a melamonzogabros com nefelina

b. monzodioritos com nefelina a monzodioritos com nefelina bandados

c. GBMf - olivina microgabros melanocráticos porfiríticos a microgabros com olivina

ICPs e Mts - ilmenita clinopiroxenitos sulfetados e magnetititos

|| || || ||| Koa - kaersutita-óxido-apatita clinopiroxenitos

EIIIIIIIIII GBEq - monzogabros com nefelina equigranulares

GBPf - Monzogabros com nefelina porfiríticos

MLGc-C - cumulatos melagábricos cimentados olivina melagabros a melagabros com olivina, melagabros laminados.

MLGc - cumulatos melagábricos - olivina melagabros a melagabros com olivina, melagabros laminados. Prõa máficas hidratadas.

UMFc - cumulatos ultramáficos - olivina

clinopiroxenitos, clinopiroxenitos com olivina. Porção hachurada - olivina kaersutita clinopiroxenitos biotita-kaersutita clinopiroxenitos com olivina

Embasamento Pré-Cambriano

Complexo Piquete (migmatitos estromáticos, biotita gnaisses, quartzitos)

+ Complexo Paraisópolis (granitos e granitoides porfiríticos)

Convenções

Contatos inferidos do maciço Ponte Nova

Lineamentos estruturais inferidos

.... Estradas principais

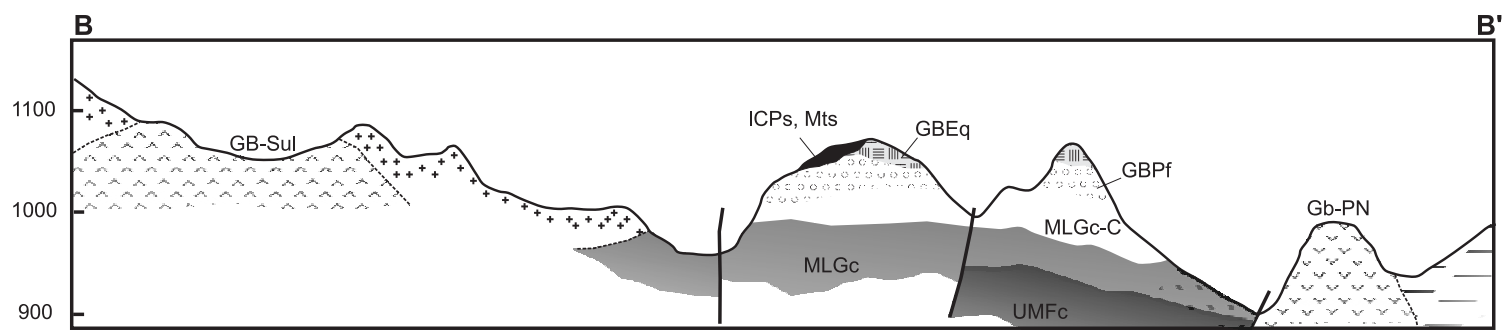

Figura 2. Mapa geológico do maciço alcalino máfico-ultramáfico Ponte Nova. Cidades de referência: CJ = Campos do Jordão (SP); SAP = Santo Antônio do Pinhal (SP); SM = Sapucaí-Mirim (MG ). Extraído de Azzone (2008). 

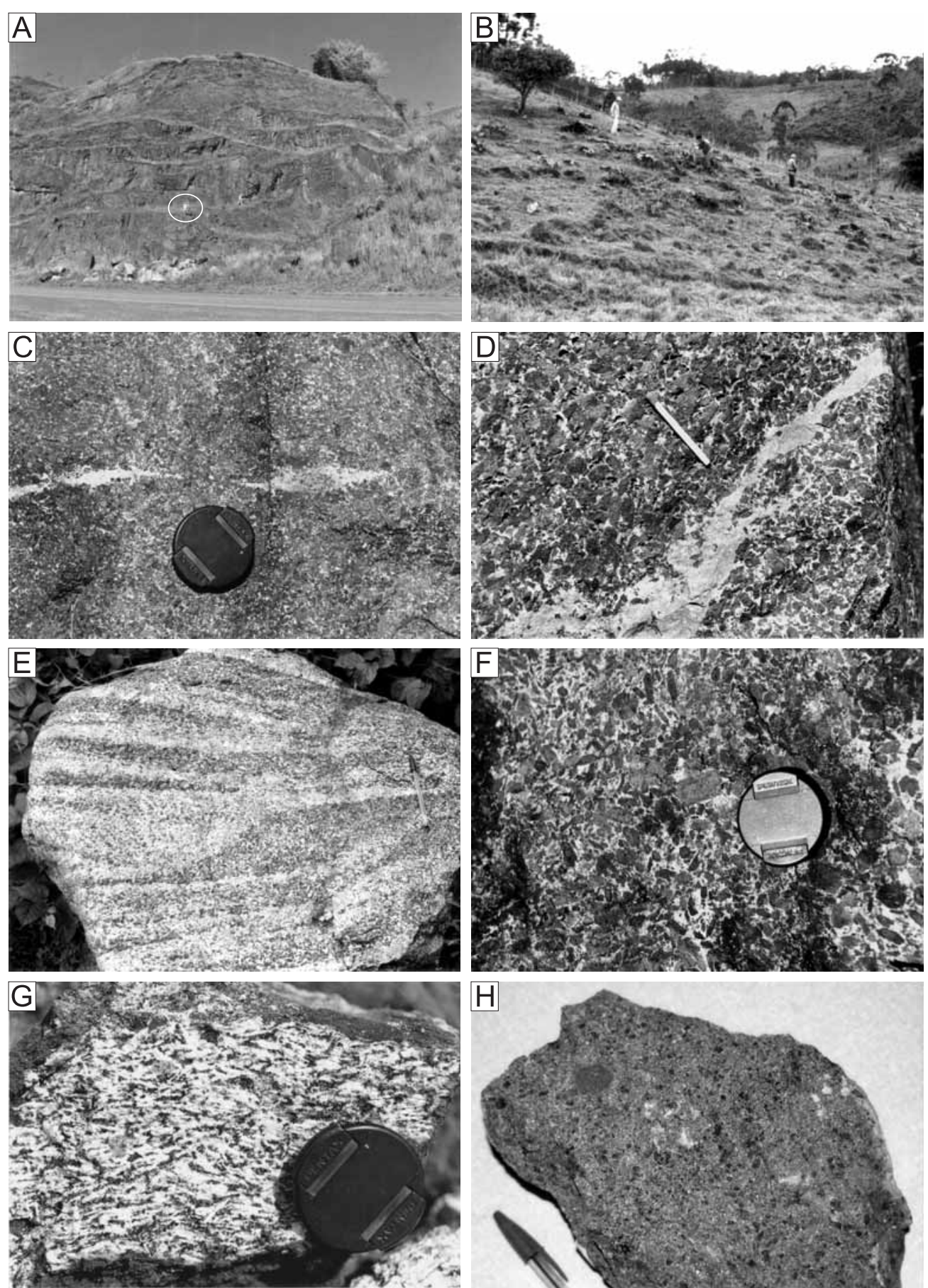

Figura 3. A. MLG c - pedreira em rochas máficas e ultramáficas cumuláticas na rodovia SP-42. 0 círculo auxilia na visualização da escala: uma pessoa. B. GB-Sul - afloramento de blocos e matacões in situ de rochas melamonzodioríticas com nefelina. C e D. MLG c - variações petrográficas e texturais macroscópicas em olivina clinopiroxenitos cumuláticos, os litotipos mais abundantes da área principal do maciço, cortados por venulações de diferenciados félsicos finais. E. GB-Bnd - estratificação plano-paralela e acanalada com alternância marcante de camadas melagábricas e leucogábricas. F. G B-Bnd presença de cumulatos gábricos pegmatoides, com cristais de clinopiroxênio maiores que $3 \mathrm{~cm}$, associados às variedades bandadas. G. G BEq - cumulatos de plagioclásio, com textura traquítica bem preservada apesar da alteração intempérica, associados às rochas de topo da área central. H. G b-PL - monzodioritos porfiríticos com fenocristais de nefelina e clinopiroxênio contendo enclave microgranular arredondado. 


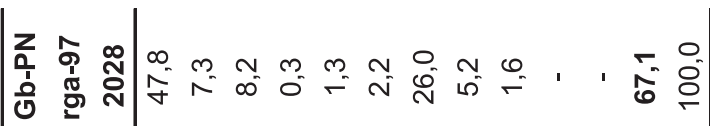

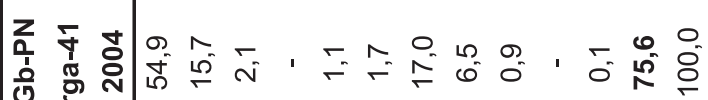

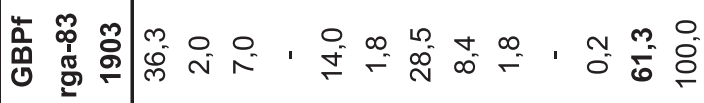

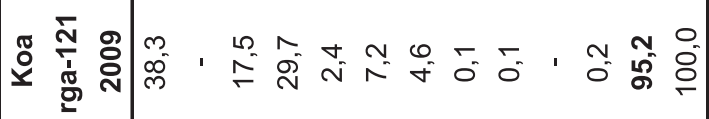

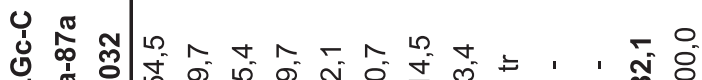

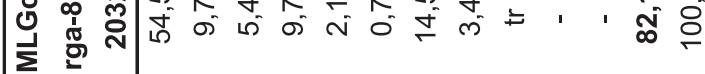
年

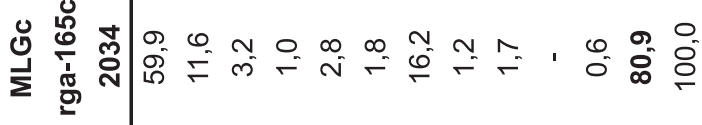
ฮั

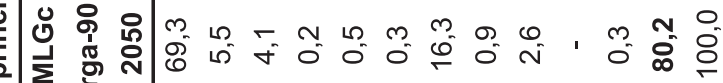

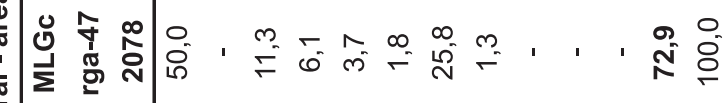

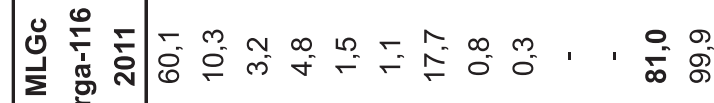

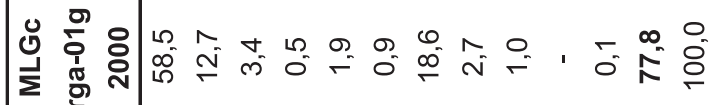

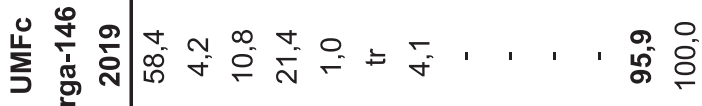

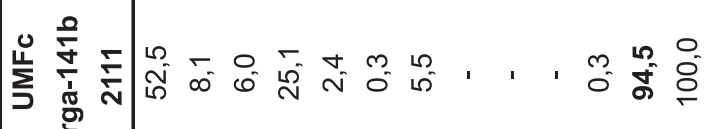

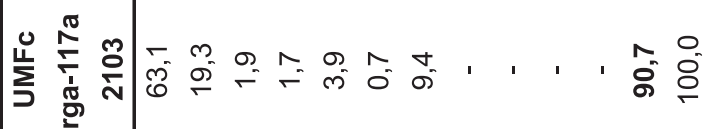
势

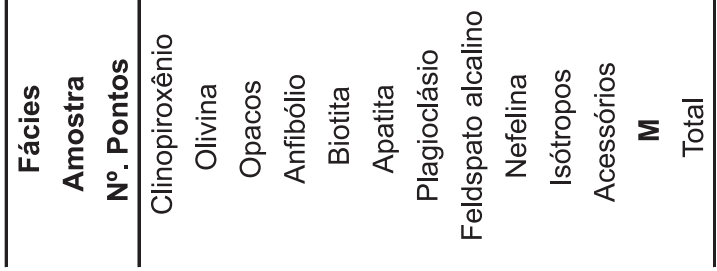

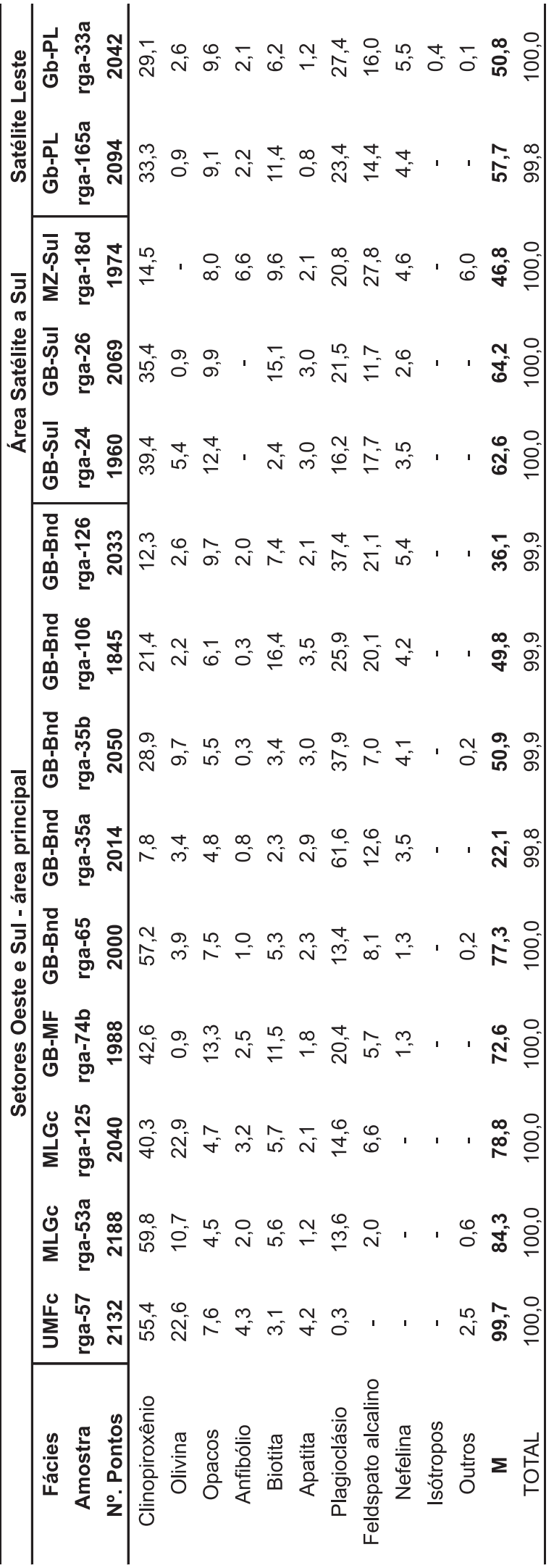


Variações Modais (em \% de volume acumulativo)

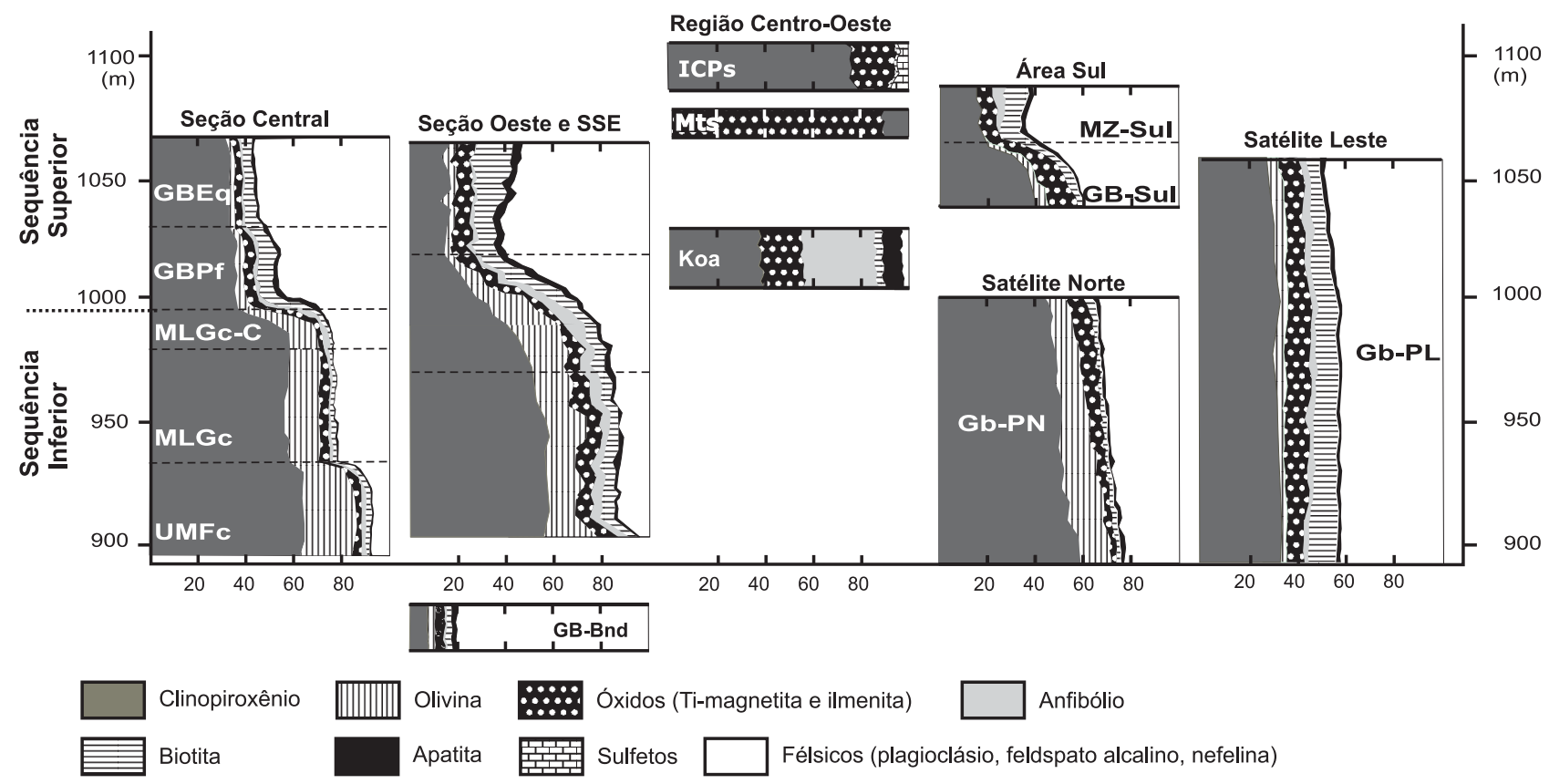

Figura 4. Variações estratigráficas e modais das diferentes fácies petrográficas do maciço Ponte Nova em relação às suas respectivas posições topográficas.

na alcançam, respectivamente, dimensões de até $1,2 \mathrm{~cm}$ e $0,5 \mathrm{~cm}$. Óxidos de Fe-Ti estão também presentes em pequenas proporções. Plagioclásio, a principal fase félsica, ocorre como cristais prismáticos a ripiformes, euédricos, de dimensões submilimétricas, e apresenta-se zonado com bordas mais albíticas. Em algumas poucas amostras reconhecem-se feições sugestivas do início de cristalização tanto dos óxidos de $\mathrm{Fe}$-Ti quanto do plagioclásio nos estágios intermediários a finais de formação do clinopiroxênio, sugerindo, assim, a participação daqueles minerais na assembleia cumulus. Intersticialmente às fases cumulus, e, em adição ao plagioclásio e minerais óxidos, aparecem ainda feldspato alcalino, minerais máficos hidratados (biotita e anfibólio) e nefelina.

Os principais afloramentos do maciço são encontrados na fácies dos cumulatos melagábricos, inclusive uma pedreira de mais de $60 \mathrm{~m}$ de extensão (Figura 3A). A observação dos afloramentos in situ indica que a fácies reúne rochas inequigranulares (com anfibólio predominando sobre biotita), evoluindo até níveis com granulação menos variável, praticamente equigranular média, que correspondem às ocorrências mais comuns.

Na região sul-sudoeste do maciço, essas rochas passam a mostrar maior concentração de minerais félsicos intersticiais e desenvolvem textura poiquilítica em plagioclásio, feldspato alcalino, biotita e anfibólio. Alguns blocos ultra- máficos ali presentes são subordinados aos melagabros na escala de afloramento. Essa associação encontra-se separada da morraria central do maciço por lineamentos estruturais, interpretados como falhamentos e eventualmente poderia representar um outro pulso magmático. Contudo, do ponto de vista petrográfico, ela é muito semelhante à do tipo litológico da morraria central.

Esta fácies caracteriza-se também pela grande diversidade petrográfica, que se reflete, por exemplo, junto à região norte do maciço, na presença de uma maior concentração de máficos hidratados. Já na porção leste, nas proximidades do contato com o embasamento e com a brecha magmática, as rochas não possuem olivina e exibem textura inequigranular fina a média, além de laminação ígnea pronunciada, com os cristais de clinopiroxênio e plagioclásio euédricos, orientados segundo direção preferencial. Essas rochas foram classificadas como melagabros laminados $(\mathrm{M}=73 \%)$ e sua ocorrência acha-se restrita a um pequeno morrote que contém em sua base variedades da fácies cumulatos ultramáficos $(\mathrm{UMFc})$.

\section{Fácies cumulatos melagábricos cimentados - MLGc-C}

Nas cotas intermediárias entre o topo e a base dos morros ocorrem rochas ainda caracterizadas como cumuláticas 

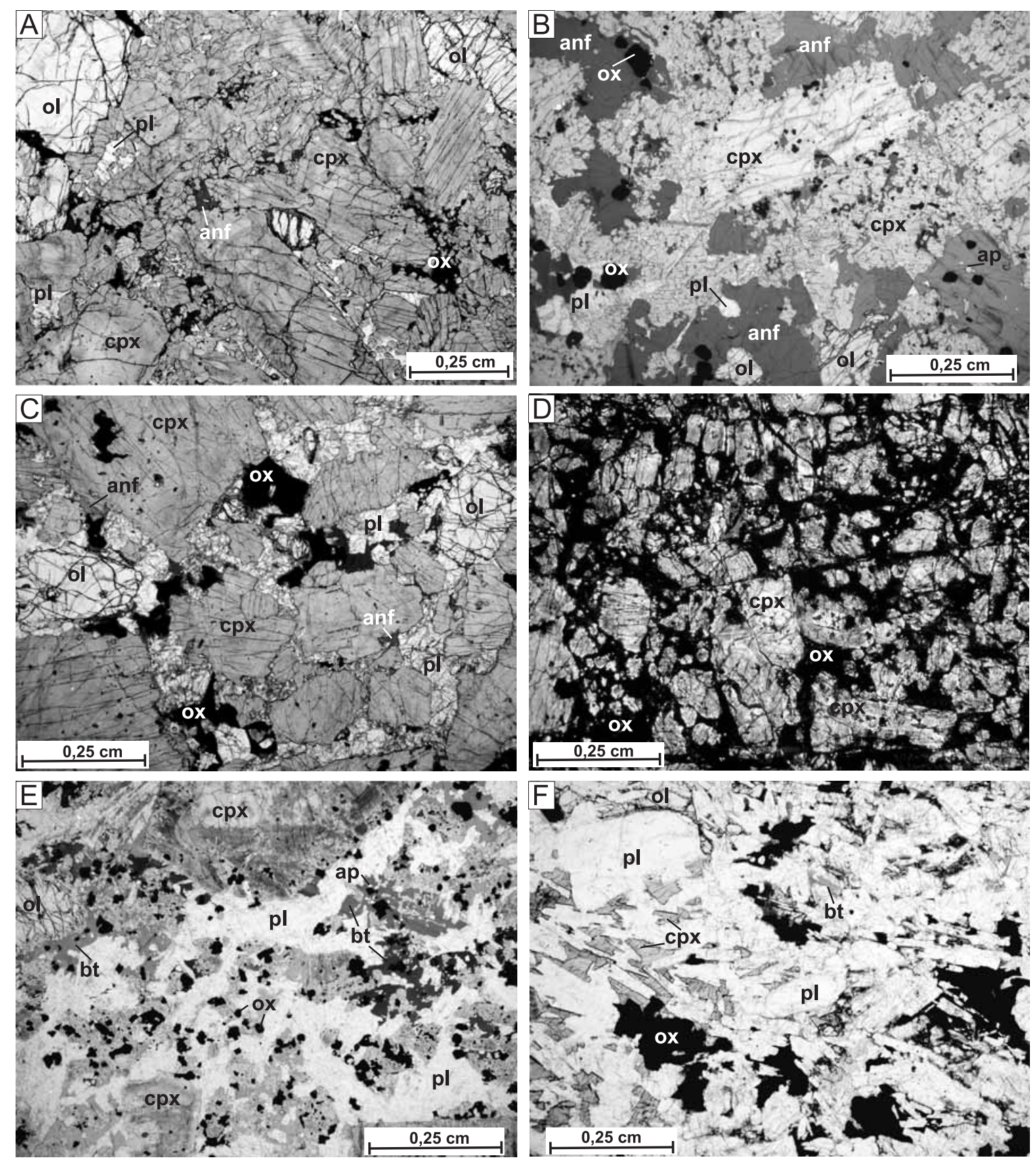

Figura 5. Aspectos microscópicos gerais de diferentes fácies petrográficas do maciço Ponte Nova. A. UMFc - cumulato ultramáfico de clinopiroxênio e olivina com preenchimento pós-cumulático associado ao sobrecrescimento das fases cumulus. B. UMFc - cumulato ultramáfico de clinopiroxênio e olivina com sobrecrescimento das fases cumulus e substituição post-cumulus por kaersutita. C. MLG c - cumulato de clinopiroxênio e olivina com aumento da cristalização de novas fases (plagioclásio, opacos e anfibólio) no preenchimento intercumulus em relação a UMFc. D. ICPs - IImenita clinopiroxenito sulfetado com acumulação de clinopiroxênio e intercumulus formado por ilmenita e sulfetos (ambos opacos). E. GBPf - Monzogabros porfiríticos com fenocristais de nefelina, clinopiroxênio e olivina e elevada concentração de plagioclásio ripiforme e biotita intersticial na matriz. F. GB-Bnd - Banda leucogábrica mostrando acumulação de cristais orientados e ripiformes de plagioclásio, com os demais minerais preenchendo os interstícios. Polarizadores paralelos. Abreviações: anf = anfibólio; ap = apatita; bt = biotita; $c p x=$ clinopiroxênio; ol = olivina; ox = óxidos de Fe e Ti; pl = plagioclásio. 
que trazem, porém, em sua composição maior concentração relativa de minerais intersticiais, por vezes, poiquilíticos. Isso se observa na região leste e norte da área principal do maciço, onde as rochas exibem textura inequigranular fina a grossa. Ali, as principais fases intersticiais são minerais máficos hidratados (anfibólio e biotita), sendo as rochas classificadas como anfibólio-olivina melagabros. $\mathrm{Na}$ porção centro-sul, nota-se, no entanto, que os cristais intersticiais, ocasionalmente poiquilíticos, de plagioclásio e feldspato alcalino predominam sobre as fases máficas finais. Na região leste-sudeste do pulso central do maciço, afloram olivina melamonzodioritos com nefelina (M $\sim 70 \%$ ), apresentando características gerais muito semelhantes às das rochas cumuláticas descritas acima, à exceção da quantidade mais alta de olivina (> 20\%). Apenas em algumas variedades ultramáficas foram registradas proporções tão expressivas desse mineral. Tanto os cristais de clinopiroxênio (principal fase máfica cumulática) quanto os de olivina são euédricos a subédricos, exibindo, na maioria das vezes, estruturas zonadas. Em alguns casos, os minerais opacos (principalmente, titanomagnetita e ilmenita) fazem também parte da assembleia cumulus, sendo encontrados muitas vezes como inclusões nos sobrecrescimentos dos cristais de clinopiroxênio. Plagioclásio, a principal fase félsica, apresenta-se mais raramente como cristais ripiformes bem desenvolvidos, formando, na maioria das vezes, cristais poiquilíticos a ameboides intersticiais, a exemplo do feldspato alcalino e nefelina.

\section{Fácies monzogabros porfiríticos - GBPf}

Esta fácies é representada por monzogabros porfiríticos com nefelina, que ocorrem na região central do maciço, com os poucos afloramentos encontrados ocupando as cristas dos morros (Figura 5E). As rochas exibem textura inequigranular porfirítica, localmente seriada, e granulação fina a média. Nota-se em algumas delas uma maior concentração de biotita intersticial; em outras, a principal fase final é feldspato alcalino como mesóstase. Nas variedades porfiríticas, os fenocristais mais comuns são de clinopiroxênio e plagioclásio, com dimensões milimétricas a centimétricas. Cristais de olivina são mais raros, aparecendo como inclusões nos fenocristais ou circundados por uma coroa de clinopiroxênio. Biotita é poiquilítica, com os cristais atingindo até $2 \mathrm{~mm}$. O mineral ocorre ainda como produto da transformação de fases cumulus de clinopiroxênio, relação esta, contudo, não observada nos grãos de clinopiroxênio da matriz.

Plagioclásio, a fase mais abundante, está presente como cristais subédricos a euédricos ripiformes, com granulação variável de 0,3 até $5 \mathrm{~mm}$. Nefelina e feldspato alcalino são fases intersticiais e formam cristais subédricos a anédricos, geralmente de aspecto ameboide. Na região oriental do maciço, registra-se a ocorrência de blocos com feições correlacionáveis às da morraria principal, classificados como gabros laminados com nefelina $(\mathrm{M} \approx 55 \%)$, ainda que o seu caráter cumulático não seja tão pronunciado.

\section{Fácies monzogabros equigranulares - GBEq}

Na região de crista da morraria central do maciço, estão presentes variedades mais félsicas, dominantemente de textura equigranular e granulação média a fina, classificadas como monzogabros equigranulares com nefelina. Os cristais de plagioclásio são ripiformes em sua maioria e os de clinopiroxênio variam entre subédricos a euédricos. Os minerais opacos (óxidos de $\mathrm{Fe}-\mathrm{Ti}$ ) são subordinados aos dois primeiros, enquanto feldspato alcalino e nefelina ocorrem intersticialmente, associados em alguns casos à mesóstase félsica. À semelhança da fácies anterior, os afloramentos são em pequeno número. Em pontos isolados, encontram-se também rochas eminentemente félsicas, com textura traquítica cumulática (Figura $3 \mathrm{G}$ ). Elas estão muito alteradas, porém, a textura em geral acha-se bem preservada, com a presença de cristais ripiformes centimétricos de plagioclásio.

Essas últimas rochas sugerem uma acumulação de plagioclásio na câmara magmática, de forma que podem representar um acamadamento originado pela ação de correntes de convecção ou estar relacionadas com a flutuação (ou flotação), por diferença de densidade, de cristais formados precocemente e concentrados em sua porção superior. Esse tipo de feição é observado em exemplos clássicos de intrusões acamadadas, tais como Skaergaard e Rhum (Wager e Brown, 1968; McBirney, 1995). Essas variedades félsicas peculiares possam talvez alcançar um volume maior, porém, não preservado face à ação da erosão.

Rochas relativamente mais félsicas $(\mathrm{M}<60)$ estão também presentes na porção norte desse pulso, junto às rochas eminentemente melagábricas, com textura orientada. Provavelmente, considerando a posição estratigráfica que ocupam, poderiam representar a cristalização de líquidos evoluídos que migraram por correntes de convecção, vindo a formar possíveis bandamentos localizados de escala métrica.

\section{Fácies gabros bandados - GB-Bnd}

$\mathrm{Na}$ região sul-sudeste do maciço, encontra-se um aglomerado de blocos e matacões com acamadamento ígneo, abrangendo uma faixa expressiva adjacente à estrada SP-42, um provável "bota-fora" formado por ocasião da sua construção. Pelo tamanho dos blocos, de escala métrica, é de se supor que eles estejam muito próximos de sua região de origem. 
As rochas bandadas, apresentando principalmente acamadamentos modais (diferenças mineralógicas), reúnem faixas que variam composicionalmente de clinopiroxeníticas até anortosíticas ou monzodioríticas, com minerais máficos intersticiais. Acamadamentos granulométricos são também comuns numa faixa de 5 a $20 \mathrm{~cm}$, alternando gabros inequigranulares de granulação variável, grossa a fina, além de camadas mais máficas ou mais félsicas. Nesses acamadamentos reconhecem-se também estruturas planares, estratificações cruzadas, cruzadas acanaladas, estruturas de escavação e truncamento de camadas (Figura 3E). Em grande parte deles nota-se ainda uma pronunciada laminação ígnea, com os cristais de feldspato (nas bandas félsicas) e de clinopiroxênio (nas bandas máficas) dispostos de forma orientada. Essas rochas são cortadas por microdiques félsicos, com espessura máxima de $3 \mathrm{~cm}$.

Logo no extremo sul desta ocorrência, observam-se blocos estratificados com grande quantidade de enclaves, estes dominantemente mais máficos, de composição gábrica e em geral angulosos; enclaves félsicos arredondados são também comuns. Todos eles poderiam corresponder a autólitos de uma mesma câmara magmática ou, como alternativa, esses tipos de gabros cumuláticos poderiam representar diferentes pulsos magmáticos na região. Neste caso, os enclaves seriam entendidos como xenólitos.

As bandas leucogábricas a anortosíticas (Figura 5F) preservam o seu caráter cumulático e exibem textura tipo traquítica inequigranular seriada, com os cristais de plagioclásio orientados e tendo dimensões variáveis entre 0,8 e $4 \mathrm{~mm}$. Com base na composição mineralógica, essas rochas são referidas como leucodioritos com nefelina e monzodioritos com nefelina.

A principal fase cumulática das bandas é o plagioclásio (labradorita e bytownita na maioria dos núcleos dos grãos), que se apresenta sempre como cristais euédricos, ripiformes. Opacos e apatita estão também presentes como minerais cumuláticos, mostrando dimensões inferiores a $0,5 \mathrm{~mm}$ e concentrações reduzidas. Em algumas bandas ocorrem esporadicamente cristais de clinopiroxênio e olivina, precocemente formados, que chegam a alcançar até $5 \mathrm{~mm}$. Nessas, os grãos de olivina são subédricos e exibem bordas de reação envolvendo opacos e provável clorita. Os cristais cumulus de clinopiroxênio possuem núcleos de diopsídio e bordas de sobrecrescimento com características de titanoaugita.

Como minerais intercumulus, além dos sobrecrescimentos das fases cumuláticas, aparecem ainda clinopiroxênio, olivina, opacos, biotita (principalmente ocupando as bordas dos grãos de opacos), feldspato alcalino, nefelina e, em alguns casos, minerais isótropos como sodalita. Apatita pode também estar presente em pequena quantidade.
Os bandamentos gábricos a melagábricos mostram textura inequigranular seriada e granulação variável de média a grossa para a assembleia cumulus principal. As características cumuláticas são iguais às descritas nas fácies anteriores, com as rochas podendo ser classificadas, na maioria dos casos, como meladioritos com nefelina.

Rochas bandadas estão também presentes na porção oeste-noroeste do maciço, em associação com monzodioritos com nefelina. Elas possuem textura variável de inequigranular média a grossa $(35<\mathrm{M}<50)$ até quase equigranular média, alternando-se bandas leucocráticas e melanocráticas. As rochas bandadas formam uma faixa restrita nas proximidades do contato com o embasamento gnáissico. Essas bandas são comumente irregulares, por vezes descontínuas, com espessura máxima de alguns centímetros nos casos mais evidentes.

Porém, nessa região, predominam rochas inequigranulares, sem bandamentos, de granulação média a grossa, onde os cristais de plagioclásio são bem formados, ripiformes, às vezes com dimensões de até $1 \mathrm{~cm}$, e possuem concentração igual ou maior que os do clinopiroxênio cumulático (diopsídio a titanoaugita, sempre com estruturas zonadas complexas). Além desses minerais, em algumas amostras a assembleia cumulus consiste de opacos, submilimétricos de aspecto granular, e, em outras, de olivina. No entanto, a olivina ocorre em muitos casos apenas na forma de inclusões nos cristais de clinopiroxênio, quando pode atingir tamanho de até 2,4 mm. Como fase cumulática, ela tem dimensões reduzidas, até submilimétricas. Os opacos são representados principalmente por titanomagnetita com "oxi-exsoluções" de ilmenita, associada à ilmenita livre (sem exsolução) e sulfetos, em sua maioria pirita.

Os cristais não cumuláticos de plagioclásio são intersticiais, variando em geral de anédricos a subédricos. Na assembleia intercumulus, além dos sobrecrescimentos dos cristais cumuláticos, aparecem também feldspato alcalino, biotita e nefelina, em alguns casos com desenvolvimento poiquilítico envolvendo as fases mais finas. Nessas rochas, a biotita também ocorre associada à alteração de olivina e de minerais opacos. Além disso, pode formar cristais subédricos a euédricos quando em contato com feldspato alcalino e nefelina.

Nas rochas bandadas, todos esses aspectos texturais são mantidos, diferindo apenas na maior quantidade dos cristais cumuláticos principais: nas bandas melanocráticas, concentra-se o clinopiroxênio; nas leucocráticas, o plagioclásio.

Para as duas regiões mencionadas do maciço, nota-se que as rochas bandadas ocorrem associadas às litologias mais félsicas nas proximidades do contato com o embasamento granítico. Dessa forma, elas poderiam estar relacionadas a uma ação mais efetiva de correntes de convecção junto dos limites do corpo, como sugerido pela presença 
de estruturas de truncamento de camadas e estratificações. Também junto à zona de contato são encontrados xenólitos decimétricos, totalmente arredondados, do embasamento com bordas de reação de dimensões centimétricas, indicativos da interação com o magma alcalino.

Associados às rochas bandadas da região sul-sudeste do maciço, aparecem também melamonzonitos com nefelina a melamonzogabros com nefelina $(70<\mathrm{M}<78)$. Eles possuem textura inequigranular média a grossa, com predominância da segunda (até $1,5 \mathrm{~cm}$ ) para o caso de cristais de clinopiroxênio, e aspecto cumulático pronunciado. A olivina, igualmente cumulática, está presente em pequena quantidade. O plagioclásio apresenta-se geralmente como cristais prismáticos a ripiformes euédricos, zonados, com dimensões submilimétricas e bordas de sobrecrescimento mais albíticas. Sua cristalização tem início nos estágios intermediários a finais de cristalização do clinopiroxênio, podendo ser também considerada uma fase cumulática secundária. Cristais intersticiais quase poiquilíticos de plagioclásio possuem ocorrência esporádica. Já o feldspato alcalino aparece como fase intersticial principal (em relação à biotita e nefelina), formando também cristais poiquilíticos sem nenhum tipo de exsolução.

Adicionalmente, ocorrem na região variedades "pegmatoides", em geral mais félsicas, com os cristais máficos cumuláticos atingindo até $3 \mathrm{~cm}$ (Figura 3F). Nessas variedades, as estruturas zonadas dos cristais de clinopiroxênio são visíveis macroscopicamente. Olivina está também presente nessas rochas, com os grãos incluídos na sua quase totalidade em cristais maiores de clinopiroxênio. Rochas com características similares são também encontradas localmente na porção noroeste do maciço, em região de crista de morro.

\section{Fácies rochas de matriz fina - GB-Mf}

Na região sul e sudeste da área principal, na região de contato com o embasamento granítico, afloram blocos de rochas porfiríticas, em alguns casos até cumuláticas, com matriz fina a muito fina, além de rochas inequigranulares de granulação fina. Petrograficamente, elas são classificadas como olivina melagabros com nefelina, melamonzogabros com nefelina e microgabros com olivina.

Por se tratar de uma região de contato, é de se esperar que elas sejam os representantes mais próximos de uma fácies de borda do maciço. Nas variedades porfiríticas, os fenocristais são essencialmente de olivina e clinopiroxênio. Nessas, as de matriz muito fina têm predomínio de fenocristais de olivina, enquanto as de matriz fina apresentam equilíbrio na distribuição dessas fases, por vezes predominando o clinopiroxênio. Nos tipos inequigranulares, notase também uma redução muito significativa na proporção de olivina, em detrimento de cristais mais desenvolvidos de plagioclásio e piroxênio, sendo as rochas classificadas como monzogabros.

Nas rochas porfiríticas de matriz fina, os fenocristais possuem dimensões de 2 a $7 \mathrm{~mm}$ e a matriz de 0,2 a $0,6 \mathrm{~mm}$. Por outro lado, naquelas de matriz muito fina, as dimensões são, respectivamente, de 0,6 a 3 mm e de 0,05 a $0,08 \mathrm{~mm}$. Já nas rochas inequigranulares, os valores extremos são de 0,3 e 3 mm.

Minerais opacos, de aspecto granular e em geral anédricos, estão presentes na matriz das rochas porfiríticas ou formam fases muito pequenas nas rochas inequigranulares. Feldspato alcalino, nefelina, biotita e anfibólio são fases intersticiais e, invariavelmente, exibem desenvolvimento poiquilítico. Apatita é o principal acessório, ocorrendo como cristais alongados, aciculares, sempre em concentrações reduzidas.

Dignas de registro são as venulações félsicas, de composição nefelina sienítica, com espessura máxima de $2 \mathrm{~cm}$ e contatos sinuosos, que cortam as rochas porfiríticas. Essas venulações representam provavelmente líquidos residuais finais que sofreram migração pela ação de processo do tipo filter pressing.

\section{Fácies kaersutita-magnetita-apatita clinopiroxenitos - Koa}

Estas rochas estão restritas à porção oeste do maciço, onde aparecem associadas com as variedades melagábricas (fácies MLGc) da região sudoeste. A única ocorrência registrada representa uma área subcircular de aproximadamente $16.300 \mathrm{~m}^{2}$, correspondendo a um pequeno morro de topografia mais acentuada em relação às rochas melanocráticas ao redor. No seu topo, estão os principais afloramentos, que se distinguem pela concentração alta de silicatos máficos (clinopiroxênio, anfibólio e biotita subordinada), minerais opacos (óxidos de Fe-Ti e sulfetos) e apatita, sendo plagioclásio o único mineral félsico presente (Tabela 1, Figura 4).

Como único mineral cumulus tem-se clinopiroxênio zonado, com núcleos de diopsídio e bordas de titanoaugita. Os cristais são subédricos a euédricos, de granulação fina a média, e por vezes se mostram corroídos por anfibólio e biotita. Não foi registrada a presença de olivina ou mesmo de qualquer indício de sua presença. Anfibólio e biotita formam quase que invariavelmente cristais poiquilíticos. Óxidos de $\mathrm{Fe}-\mathrm{Ti}$, sulfetos e apatita são de granulação fina a muito fina, euédricos a subédricos ou mesmo arredondados, e estão em sua totalidade englobados por anfibólio e biotita.

O modo de ocorrência, a densidade maior dessas rochas quando comparadas às demais do maciço e as carac- 
terísticas texturais são sugestivas de sua natureza peculiar de formação, associada principalmente aos estágios póscumuláticos de cristalização, sob uma ação efetiva de fluidos ricos em voláteis que teriam interagido com cumulatos previamente formados.

\section{Fácies área de exposição sul - GB-Sul e MZ-Sul}

A área de ocorrência desta fácies, de aproximadamente $1 \mathrm{~km}^{2}$, e separada da principal (em superfície) pelo embasamento granítico, foi delineada a partir de controle geomorfológico e de afloramento. Com base nestes parâmetros, nota-se que as rochas gábricas ocorreriam nas cotas topográficas mais baixas, até a região de meia encosta, onde há uma quebra no relevo e subsequente declive abrupto onde já afloram rochas do embasamento Pré-Cambriano.

Nessa região, é difícil diferenciar fácies com algum controle geomorfológico significativo. Desse modo, prefere-se tratar as rochas do corpo satélite como integrantes de uma mesma unidade principal.

As rochas mais abundantes e com melhores exposições na área são os melamonzonitos com nefelina. Possuem caráter porfirítico, matriz fina a média e fenocristais euédricos de clinopiroxênio e olivina com dimensões entre 3 e $8 \mathrm{~mm}$. Nota-se que a maioria dos fenocristais de olivina exibe bordas compostas por agregados de minerais opacos. São rochas muito semelhantes às da fácies gabros porfiríticos (GBPf), que ocorrem na região central da área principal do maciço.

$\mathrm{Na}$ matriz, os cristais em parte ripiformes de plagioclásio, os granulares subédricos a anédricos de olivina e os aciculares de apatita apresentam dimensões variáveis entre 0,2 e $0,5 \mathrm{~mm}$. Porém, nela predominam em realidade minerais intersticiais com formas anédricas e irregulares (por exemplo, plagioclásio com baixo teor de anortita, feldspato alcalino, nefelina e biotita) e tamanho compreendido entre 0,3 e $0,8 \mathrm{~mm}$. Dessas fases finais, o principal mineral presente é o feldspato alcalino, na forma predominantemente de cristais poiquilíticos, incluindo os demais constituintes da matriz (plagioclásio, opacos, apatita). Algumas dessas variedades porfiríticas contêm enclaves máficos e félsicos, representativos dos cumulatos da área principal.

É no corpo satélite que se encontra uma das rochas mais evoluídas do maciço, os monzonitos com nefelina (MZ-Sul), que afloram na forma de matacões in situ. Trata-se de uma pequena ocorrência reunindo rochas mesocráticas a leucocráticas de textura inequigranular porfirítica, com fenocristais de plagioclásio e feldspato alcalino variando na maioria dos casos de $2 \mathrm{~mm}$ a $1 \mathrm{~cm}$.
De forma geral, esses monzonitos têm clinopiroxênio, como cristais euédricos, anfibólio, com pleocroísmo acastanhado a marrom-alaranjado e substituindo a fase anterior, e, principalmente, biotita como principais minerais máficos. O último mostra textura poiquilítica, porém, ocorre também como cristais precocemente formados, subédricos a euédricos, zonados e alongados, com dimensões até centimétricas. Quanto aos minerais opacos, estão presentes titanomagnetita com lamelas de "oxi-exsolução" de ilmenita e sulfetos (principalmente pirita), todos de dimensões submilimétricas. Cristais de plagioclásio são predominantemente euédricos e ripiformes, alcançando até $5 \mathrm{~mm}$. Feldspato alcalino e nefelina ocorrem como cristais poiquilíticos, de contorno irregular a ameboide, que atingem, respectivamente, até 8 e $4 \mathrm{~mm}$. Apatita constitui um dos principais acessórios, sendo submilimétrica e euédrica a subédrica. Carbonatos ocorrem intersticialmente.

Essas rochas monzoníticas (MZ-Sul) exibem por vezes granulação muito grossa, com cristais de feldspato alcalino, plagioclásio e biotita de até $2 \mathrm{~cm}$. As feições mineralógicas e texturais sugerem que esse litotipo representa uma evolução das rochas melamonzoníticas com nefelina presentes no mesmo corpo (GB-Sul). Por exemplo, em um dos afloramentos de rochas tipicamente melamonzoníticas, encontram-se bolsões irregulares consistindo em material semelhante ao dos monzonitos com nefelina de granulação média, indicando, portanto, uma evolução gradativa de variedades melanocráticas a félsicas.

Além disso, ocorrem pontualmente em afloramento in situ (Figura 3B), rochas com grande quantidade de biotita poiquilítica, mesmo em variedades melanocráticas, definidas como melamonzodioritos com nefelina, e apresentando megacristais poiquilíticos zonados de até $3 \mathrm{~cm}$ de tamanho. A concentração de biotita nessas amostras é de aproximadamente $15 \%$, enquanto que nos demais litotipos a proporção diminui para menos de $3 \%$.

Registra-se também a ocorrência de blocos de rochas granulares finas, praticamente subvulcânicas, possivelmente representativos de algum dique tardimagmático ou a uma fácies de borda do corpo satélite. São classificadas como melamonzonitos com nefelina de textura inequigranular fina, com as dimensões dos cristais variando entre 2,4 e 0,2 mm. Essas rochas estão cortadas por bolsões e venulações félsicas, com grande quantidade de nefelina e cavidades miarolíticas, representando provavelmente líquidos residuais finais. Além disso, contêm enclaves arredondados em grande parte gábricos, que atingem $2 \mathrm{~cm}$ de tamanho. As fases finais intersticiais (feldspato alcalino, nefelina e biotita) são comumente poiquilíticas. Os cristais de clinopiroxênio e plagioclásio são euédricos e subédricos, e a concentração de olivina é bastante reduzida em relação aos tipos anteriores. 


\section{Fácies pulso norte - Gb-PN}

No extremo norte do maciço, ocorrem olivina melamonzodioritos a melamonzodioritos com olivina $(65<\mathrm{M}<76)$, que devem representar, conforme sugerem as evidências geomorfológicas e as características petrográficas, um pulso diferenciado. Nas bordas aflorantes da fácies (a sul) são encontradas rochas mais finas, de textura equigranular fina e mesmo porfiríticas de matriz fina, com fenocristais de clinopiroxênio imersos em massa dominantemente de granulação média. No centro da fácies, correspondendo às cotas topográficas mais elevadas, estão presentes rochas mais félsicas, de textura inequigranular e granulação fina a média, com cristais esporádicos maiores. $\mathrm{O}$ feldspato alcalino é de ocorrência intersticial, sobretudo na mesóstase félsica. Ademais, a principal fase máfica hidratada, ainda em concentração reduzida, é a biotita. Quando associada ao feldspato alcalino apresenta contatos subédricos a euédricos. Nefelina ocorre intersticialmente aos cristais de plagioclásio.

\section{Fácies pulso leste - Gb-PL}

Na porção centro-leste do maciço, ocorrem nefelina monzodioritos a monzodioritos com nefelina $(50<\mathrm{M}<58)$. Esta fácies apresenta pequeno zoneamento, com rochas mais máficas e porfiríticas encontradas in situ em cotas topográficas mais baixas, ou seja, junto ao rio ou nas proximidades das bordas da fácies. Nas rochas topográficas e imediatamente acima dos tipos mais máficos, a textura se mostra ainda porfirítica e com matriz de granulação fina, porém, elas são mais félsicas que as anteriores e contêm grande quantidade de xenólitos gábricos cumuláticos e graníticos, além de enclaves máficos microgranulares arredondados (Figura 3H). Já nas rochas que afloram in situ na porção sul-sudeste da fácies a textura predominante é inequigranular seriada.

Nas variedades inequigranulares, os grãos de olivina, em geral anédricos, arredondados, possuem dimensões entre 0,6 e $6 \mathrm{~mm}$ e acham-se circundados por uma coroa de biotita ou, então, estão incluídos em cristais maiores de clinopiroxênio, indicando instabilidade com as fases finais. Além disso, são alterados em suas bordas, provavelmente, para clorita ou mesmo serpentina verde. O principal mineral máfico é o clinopiroxênio (titanoaugita), variando na forma de euédrico, nos cristais mais desenvolvidos (até $7 \mathrm{~mm}$ ), a subédrico ou, mesmo, anédrico nos grãos representando possíveis xenocristais. Cristais nitidamente fraturados, mostrando formas subédricas, angulosas, estão também presentes, e são sugestivos de xenocristais incorporados ao magma. Nos cristais menores, de dimensões submilimétricas, as formas variam entre subédrica a anédrica. A maioria dos cristais exibe zoneamento, por vezes com padrões bastan- te complexos, e também geminação, principalmente os de maior tamanho.

Os minerais opacos apresentam sempre aspecto granular e, quando bem desenvolvidos, formam cristais subédricos, porém, nas fases mais finas, são praticamente anédricos. Plagioclásio é o mineral félsico mais importante, ocorrendo como cristais tabulares de forma euédrica a subédrica. Na maior parte das vezes, ele é zonado e mostra geminação polissintética. Alguns núcleos de cristais têm composição labradorítica, que evolui, no entanto, para andesínica. O feldspato alcalino ocorre intersticialmente ao plagioclásio, o mesmo sucedendo com os feldspatoides (nefelina e sodalita).

Nas rochas porfiríticas mais félsicas, a matriz é fina, com fenocristais de titanoaugita e subordinadamente de olivina. Alguns fenocristais de plagioclásio, com dimensões de até $3 \mathrm{~mm}$, são também reconhecidos. Anfibólio e biotita ocorrem como fases intersticiais finais juntamente com feldspato alcalino e feldspatoides, exibindo todos esses minerais forma anédrica, ameboide com feições indicativas de coprecipitação. Em alguns casos, a biotita aparece na forma de cristais poiquilíticos envolvendo os constituintes da matriz. A dimensão dos fenocristais é a mesma dos maiores cristais presentes nas variedades inequigranulares. As rochas porfiríticas contêm ainda xenólitos de composição granítica, que se apresentam envolvidos por uma coroa de microcristais de augita.

Titanita, de forma anédrica, aparece como fase menor nos estágios finais de cristalização. Apatita, de aspecto granular, forma arredondada ou de agulha, ocorre tanto associada com cristais de clinopiroxênio quanto junto aos membros da matriz. Carbonatos, de ocorrência intersticial, e epidoto, na forma de microcristais euédricos em associação com plagioclásio, parecem estar relacionados a estágios tardios ou a episódios de alteração hidrotermal.

Nos tipos litológicos porfiríticos mais ricos em máfi$\cos (\mathrm{M}<50)$, nota-se o aumento da quantidade de fenocristais euédricos de clinopiroxênio e olivina. Nessas rochas, a grande maioria dos cristais de olivina não mais apresenta coroas de biotita quando em contato com os félsicos, e o único acessório presente é apatita. Além disso, elas são cortadas por venulações predominantemente félsicas de composição nefelina monzossienítica, tendo cristais alongados de biotita como principal fase máfica. Essas ocorrências são interpretadas como representativas de um pulso magmático posterior ao das fácies anteriormente descritas.

\section{Fácies minério - ICPs e Mts}

Na região centro-oeste do maciço, abrangendo o morro de maior altitude topográfica, são encontradas rochas bas- 
tante particulares, classificadas como ilmenita clinopiroxenitos sulfetados (ICPs, M > 95), que mostram na maioria das vezes contactos abruptos e sinuosos com os tipos gábricos adjacentes. Nessas variedades ultramáficas, os cristais cumuláticos de clinopiroxênio, com tamanho de até $1 \mathrm{~cm}$, estão completamente envolvidos por ilmenita intersticial (Figura 5D). Contudo, o último mineral aparece ainda na forma de cristais euédricos, zonados, como inclusões no clinopiroxênio. Por vezes, nota-se também a presença de grãos de biotita próximos às bordas da ilmenita. Os sulfetos, representados em sua maioria por pirita e pirrotita, estão associados às porções marginais dos grãos intersticiais de ilmenita ou, então, formam cristais poiquilíticos, que sugerem nestes casos a sua mobilização por ação hidrotermal. Porém, cristais bem formados, euédricos, do mineral são ainda identificados, apontando para uma origem magmática primária.

Essa litologia contém enclaves microgranulares de rochas de aspecto muito semelhante à dos diques tefríticos e dos gabros porfiríticos que afloram nas proximidades. Por sua vez, esses enclaves parecem indicativos que o corpo de ilmenita clinopiroxenitos formou-se posteriormente às rochas do pulso central e mesmo em relação a alguns diques que cortam o maciço, o que permite colocar essa fácies como uma das últimas manifestações magmáticas da ocorrência de Ponte Nova. Principalmente associados às bordas dos enclaves, mas também observados no interior da matriz, estão presentes cristais de biotita, muito possivelmente representando um produto de reação dos xenólitos com o magma.

Ademais, observa-se a ocorrência de enclaves de ilmenita clinopiroxenitos de granulação fina em ilmenita clinopiroxenitos de granulação grossa, que são os predominantes na região. Estes últimos poderiam corresponder a autólitos de uma porção talvez mais basal do mesmo pulso.

Isoladamente, ainda que não localizados in situ, foram também reconhecidos dois pequenos blocos de uma fácies muito característica, um possível horizonte ou banda, definida como magnetitito (Mts), contendo maior abundância de óxidos (Ti-magnetita e ilmenita) relativamente ao clinopiroxênio.

A compactação dessas rochas (Hunter, 1996) é bastante pronunciada, com os cristais de clinopiroxênio alongados e orientados segundo uma determinada direção. É interessante notar que muitos enclaves, quer de rochas gabroides, quer de ilmenita clinopiroxenitos finos, apresentam-se igualmente alongados e achatados na mesma direção que os cristais de clinopiroxênio. Tal feição parece sugestiva que o pulso representado pelos ilmenita clinopiroxenitos penetrou a câmara magmática enquanto algumas rochas do pulso central ainda não se encontravam totalmente cristalizadas.

\section{Brecha magmática - $\mathrm{BRCH}$}

Na região extremo leste do maciço, encontram-se afloramentos in situ de um corpo de brecha de contorno irregular. Ela apresenta grande diversidade petrográfica, reunindo fragmentos desde rochas ultramáficas, gábricas melanocráticas, máficas e félsicas, de tamanho variável, além de cristais menores que $1 \mathrm{~cm}$ e líticos com até $40 \mathrm{~cm}$.

Um aspecto relevante é a ocorrência de rochas de matriz de granulação fina a afanítica, coloração escura ou ainda esverdeada, com grande quantidade de cristais angulosos, alguns lenticulares, e sulfetos disseminados. Microvênulas félsicas, descontínuas e orientadas, são também reconhecidas. Os fragmentos líticos, quando presentes, não chegam a ultrapassar $5 \mathrm{~cm}$ de tamanho. Essas variedades poderiam representar porções diferenciadas do edifício vulcânico responsável pela brecha.

Petrograficamente, a matriz fina é submilimétrica, em média $0,03 \mathrm{~mm}$, e tem como principal constituinte microcristais ripiformes de plagioclásio em sua maioria orientados, indicando estrutura de fluxo magmático. Nota-se também a presença de cristais poiquilíticos alongados de biotita com dimensões de até $0,3 \mathrm{~mm}$. De aspecto mais granular e com dimensões tão reduzidas quanto a do plagioclásio, são os cristais de minerais opacos, principalmente sulfetos. Os cristais formados e os possíveis fragmentos de cristais incorporados estão representados por vários minerais: clinopiroxênio, olivina, plagioclásio, biotita e opacos. Eles têm em sua maioria dimensões submilimétricas, atingindo até $0,5 \mathrm{~mm}$, são dominantemente euédricos, poucos arredondados, e alguns estão em completo desequilíbrio com a matriz, mostrando bordas de reação.

Macroscopicamente, são reconhecidas feições indicativas de fluxo magmático. Os fragmentos líticos, na maioria dos casos arredondados, estão representados principalmente pelas variedades gábricas de caráter mais máfico do maciço. Fragmentos do embasamento granítico e quartzítico e líticos arredondados de rochas de textura vitrofírica, provavelmente de diques regionais, com fenocristais submilimétricos de plagioclásio ripiforme, ocorrem em menor proporção. Outros fragmentos milimétricos mostrando textura similar são lenticulares, provavelmente como resultado da interação da brecha com o magma, com a forma do fragmento acompanhando o sentido do fluxo.

Os afloramentos in situ foram importantes para elucidar as ocorrências de rochas com matriz afanítica e abundantes xenocristais e fenocristais nessa área do maciço. Em trabalhos anteriores (Alves, 1978; Alves, Ruberti, Vlach, 1992) elas foram interpretadas, respectivamente, como sendo diques ou rochas porfiríticas de borda. Com os novos dados, verifica-se que elas em realidade parecem estar 
associadas a um conduto vulcânico, representando, assim, uma brecha de conduto.

\section{Vênulas, bolsões e diferenciados félsicos - DifF}

Diferenciados félsicos das fácies plutônicas estão presentes no maciço Ponte Nova na forma de diques, vênulas e possivelmente bolsões (Figuras 3C e 3D).

Os diques e as venulações félsicas são representados por rochas leucocráticas a mesocráticas $\left(\mathrm{M}^{\prime} \sim 25\right)$ de textura inequigranular fina a média. Na sua totalidade, esses corpos possuem composição monzonítica a monzossienítica, chegando excepcionalmente a nefelina sienítica. Nessas rochas, os máficos principais são anfibólio e biotita, com clinopiroxênio e opacos ocorrendo de forma subordinada. Nas rochas da fácies cumulatos melagábri$\cos$ (MLGc) encontram-se também venulações félsicas, que podem ser até definidas como diques. Essas venulações, provavelmente formadas por mecanismo do tipo filter pressing, estão orientadas praticamente segundo a mesma direção dos principais diques máficos que cortam o maciço (N45E e N45W, com mergulho alto). Nas rochas da fácies área sul (GB-Sul) e da fácies pulso leste (Gb-PL), as venulações são irregulares e, composicionalmente, variam de monzossienitos com nefelina a nefelina sienitos. Em alguns casos, esses diferenciados finais formam bolsões, como sugerido pela ocorrência esporádica de blocos desses litotipos em fácies de caráter melanocrático cumulático.

\section{Suíte de diques do maciço Ponte Nova (DM-LGT e DF-TeF)}

A suíte de diques, formados em grande parte por rochas afaníticas ou porfiríticas de matriz afanítica, que_cortam o maciço reúne variedades félsicas e mesocráticas a melanocráticas. Poucos deles são encontrados in situ e, assim como a maioria das rochas do maciço, os afloramentos de blocos predominam. Nestes, os diques aparecem como corpos penetrando os blocos de rochas gábricas ou, então, na forma de blocos constituídos somente de rochas afaníticas, interpretadas como possíveis diques.

Os diques mesocráticos a melanocráticos possuem granulação fina, sendo geralmente porfiríticos, com fenocristais de dimensões centimétricas em alguns casos. Muitos podem ser classificados como lamprófiros, camptonitos em sua maioria, segundo as características descritas por Rock (1991), Woolley et al. (1996) e Le Maitre (2002). Além de fenocristais, é também comum apresentarem "xenocristais" com bordas de reação, ocelos e amígdalas. Em realidade, grande parte dos diques (quan- do presentes in situ) exibe estrutura zonada, com bordas afaníticas a praticamente vítreas, centros porfiríticos e porções intermediárias formadas, em alguns casos, por zonas com amígdalas e ocelos. Os fenocristais mais frequentes são de clinopiroxênio e anfibólio; olivina ocorre apenas em alguns corpos e, geralmente, acha-se envolta por uma coroa de anfibólio e biotita. No interior do maciço, esses corpos possuem espessura variável, que alcança até $40 \mathrm{~cm}$. A sua matriz é constituída por cristais de anfibólio prismático, opacos arredondados de aspecto euedral e félsicos intersticiais, além de alguns cristais ripiformes de plagioclásio.

De grande importância e caráter dominantemente mesocrático são os diques tefríticos. Microscopicamente, eles possuem feições mineralógicas similares às dos camptonitos, diferenciando-se, no entanto, sobretudo pela textura, ausência de estrutura zonada e por conter fenocristais de plagioclásio.

Blocos microgábricos melanocráticos aparecem, em alguns casos, junto às rochas do embasamento e ao lado de fácies mais félsicas, podendo representar diques. Eles mostram as mesmas características mineralógicas gerais das rochas melanocráticas encontradas no maciço.

Os diques félsicos (leucocráticos a mesocráticos) apresentam textura fanerítica muito fina a afanítica, sendo alguns porfiríticos, com fenocristais tabulares de feldspato e aciculares de clinopiroxênio e anfibólio. Quanto à coloração, variam de verde musgo a cinza escuro quando frescos, e de cinza claro ou verde claro quando alterados. Possuem espessura entre 2 e $25 \mathrm{~cm}$, quando observados in situ ou interceptando as rochas do maciço, e contatos via de regra retilíneos. Composicionalmente, variam entre tefrito-fonolíticos e fonotefritos. A matriz é composta por anfibólio prismático, grãos subédricos de clinopiroxênio, plagioclásio ripiforme a poiquilítico, biotita, opacos, apatita, feldspato alcalino, nefelina e isótropos intersticiais. Diques fonolíticos, invariavelmente porfiríticos com fenocristais de feldspato alcalino, são encontrados nas imediações do maciço penetrando o embasamento granítico. Alguns diques fonotefríticos são cortados por venulações de composição nefelina sienítica, de granulação um pouco mais grossa que a dos diques.

Cabe ressaltar que o magmatismo alcalino em questão não se restringe às cercanias do maciço Ponte Nova. Em toda essa região da Serra da Mantiqueira, desde Sapucaí Mirim até Santo Antônio do Pinhal, ocorre uma extensa quantidade de diques cortando as rochas do embasamento e caracterizando séries de lamprófiros máficos a ultramáficos e traquitos a fonolitos. Os trabalhos de Alves, Ruberti e Vlach (1992) e Ruberti et al. (1993) fornecem maiores informações sobre as características gerais desses corpos. 


\section{CLASSIFICAÇÃO DAS ROCHAS CUMULÁTICAS}

A nomenclatura das variedades cumuláticas, segundo Wager, Brown e Wadsworth (1960), que leva em consideração a abundância dos minerais cumulus, permite identificar os casos do maciço Ponte Nova eminentemente como clinopiroxênio-olivina cumulatos. As exceções consistiram nas bandas leucocráticas da fácies GB-Bnd, identificadas como plagioclásio cumulatos, e as variedades da fácies minério, classificadas como clinopiroxênio-ilmenita cumulatos (ICPs) e magnetita-ilmenita cumulatos (MTs).

Conforme a classificação textural de Wager, Brown e Wadsworth (1960), que considera a composição do material intercumulus, as rochas cumuláticas do maciço representariam na sua grande maioria ortocumulatos, com mesocumulatos em alguns poucos casos. Não foram encontradas variantes adcumuláticas. Nesse sentido, o preenchimento pós-cumulático dessas rochas envolve o sobrecrescimento com diferença composicional das fases cumulus principais, como sugerem as estruturas zonadas, em especial dos cristais de clinopiroxênio, ou a cristalização de novas fases mineralógicas intersticiais ou, então, ambas as feições em uma mesma amostra.

No entanto, de acordo com a proposta de Irvine (1982), que classifica as rochas cumuláticas sob aspectos estritamente ligados à quantidade de material intercumulus, os cumulatos do maciço se colocariam entre mesocumulatos e ortocumulatos (respectivamente, $7-25 \%$ e $25-50 \%$ de material intercumulus).

Por outro lado, considerando a sistemática de Hunter (1996), que utiliza termos mais descritivos, nota-se que há ainda certa subjetividade na fixação de limites para os termos intermediários entre rochas totalmente densificadas e totalmente cimentadas. Para o maciço Ponte Nova, os diferentes tipos texturais permitem classificações distintas para os cumulatos mais proeminentes. Assim, por exemplo, na fácies cumulatos ultramáficos (UMFc), junto às ocorrências da região central da área principal, as rochas são altamente densificadas (Figura 5A); já na região norte, elas possuem um maior componente de cimentação, devido à presença de cristais poiquilíticos de anfibólio e biotita (Figura 5B). Na fácies cumulatos melagábricos (MLGc), nota-se novamente que na região central do maciço, em sua área aflorante maior, as rochas são altamente densificadas (Figuras 3C e 5C), inclusive com cristais ripiformes de plagioclásio no intercumulus; já nas partes sul e norte da fácies, a cimentação possui um componente relevante, face à maior ocorrência de cristais intersticiais a poiquilíticos de feldspato, anfibólio e biotita. $\mathrm{Na}$ fácies cumulatos melagábricos cimentados (MLGc-C), há um aumento na concentração volumétrica dos intercumulus, sendo as ro- chas mais cimentadas. Na fácies minério (ICPs), as rochas são altamente densificadas.

\section{IDADES K/Ar}

Há certo conflito entre os dados geocronológicos constantes da literatura para o maciço Ponte Nova. Miniolli (1971), discutindo a geocronologia e a extensão geográfica do vulcanismo basáltico do Cretáceo Inferior no Brasil Meridional, apresenta duas datações $\mathrm{K} / \mathrm{Ar}$ em rochas relacionadas ao maciço, por ele denominado de Campos do Jordão. Nesse trabalho, foram datadas duas amostras de kentallenito (monzonito melanocrático), que deram idades de $117,3 \pm 6,5 \mathrm{Ma}$ e 128,6 \pm 8,0 Ma (valores corrigidos por Sonoki e Garda, 1988). Hama et al. (1979), em trabalho sobre determinações radiométricas por $\mathrm{Rb} / \mathrm{Sr}$ e K/Ar em rochas aflorando na região sul de Minas Gerais e leste de São Paulo, realizaram também uma datação em biotita de um peridotito do maciço, atribuindo-lhe uma idade $\mathrm{K} / \mathrm{Ar}$ de $88 \pm 5,5 \mathrm{Ma}$ (corrigida por Sonoki e Garda, 1988). Esse valor é o mais citado nos trabalhos subsequentes que mencionam a ocorrência, inclusive no texto de Cavalcante et al. (1979), até então tido como a principal referência sobre o maciço.

Porém, a idade fornecida no trabalho de Hama et al. (1979), utilizando concentrados de biotita, mostra teores de $\mathrm{K}$ abaixo de $2 \%$, com erros analíticos relativamente elevados, comprometendo, assim, a confiabilidade da análise. Por outro lado, no trabalho de Miniolli (1971), a idade maior $(128,6 \pm 8,0 \mathrm{Ma})$, obtida em rocha total, é também pouco confiável, e apenas a menor $(117,3 \pm 6,5 \mathrm{Ma})$, em concentrados de biotita $(6,8 \%$ de $\mathrm{K})$, poderia ter eventualmente algum significado. Entretanto, as ocorrências alcalinas presentes nas adjacências do maciço, incluídas no setor norte da Província Serra do Mar, apresentam idades no intervalo de 80 a $90 \mathrm{Ma}$ e, ainda mais, as que fazem parte da Província do Lineamento de Cabo Frio, na faixa de 80 - $55 \mathrm{Ma}$.

Nesse sentido, a fim de sanar as dúvidas suscitadas pelos dados geocronológicos disponíveis, foram efetuadas novas análises pelo método K-Ar no Centro de Pesquisas Geocronológicas (CPGeo) do Instituto de Geociências. Foram selecionadas amostras de diferentes fácies e pulsos magmáticos do maciço e, subsequentemente, preparados concentrados de biotita, totalizando cinco análises.

Os procedimentos analíticos empregados são discutidos em Amaral et al. (1966), com modificações. As análises de $\mathrm{K}$ foram realizadas em duplicata, quantificadas por meio de fotometria de chama (aparelho Micronal, modelo B-262), e o argônio extraído em ultra-alto vácuo (pressões inferiores a $10^{-7} \mathrm{~mm}$ de $\mathrm{Hg}$ ) e purificado em fornos de cobre e titânio. A reprodutibilidade do método é 
da ordem de 2 a 3\%, com base na utilização de padrões laboratoriais. Para o cálculo das idades foram usadas as constantes recomendadas por Steiger e Jager (1977): $\lambda \beta=4,962.10^{-10}$ anos $^{-1} ; \lambda \mathrm{k}=0,581.10^{-10} \operatorname{anos}^{-1} ;\left({ }^{40} \mathrm{Ar} /{ }^{36} \mathrm{Ar}\right)$ atm $=295,5 \mathrm{e}^{40} \mathrm{~K}=0,01167 \% \mathrm{~K}_{\text {total }}$.

Os dados obtidos (Tabela 2) indicam idades variando entre 89,6 Ma e 86,7 Ma, com valor médio de 87,6 Ma e desvio padrão de 1,3 Ma. Os erros individuais de cada análise variaram entre 2,6 Ma e 3,6 Ma. Os teores de K, todos acima de 5\%, conferem boa confiabilidade às análises. Esses teores poderiam ser ainda melhor quantificados não fosse a impossibilidade de obtenção, para a maioria dos casos, de cristais completamente livres de inclusões de apatita e óxidos de Fe e Ti.

Dessa forma, as idades obtidas possibilitam perfeitamente o enquadramento do maciço alcalino Ponte Nova no cronogrupo do setor norte da Província Serra do Mar (Riccomini, Velázquez, Gomes, 2005). Já os dados de Miniolli (1971), embora sejam tidos como associados à ocorrência, ou contaram com severas dificuldades analíticas ou então de amostragem ou, como mais provável, não se referem a rochas do maciço, correspondendo talvez às variedades vulcânicas da Formação Serra Geral.

\section{DISCUSSÃO E CONSIDERAÇÕES}

\section{Evolução geológica do maciço Ponte Nova}

As informações coligidas no presente trabalho permitem interpretar a suíte do maciço como sendo o resultado de sucessivos pulsos magmáticos que penetraram o embasamento granítico-gnáissico Pré-Cambriano há aproximadamente 87,6 Ma. A diversidade de rochas máficas e ultramáficas encontrada, com uma sequência de cristalização bem definida, que teve início com a formação de olivina seguida de clinopiroxênio, indica a cristalização fracionada como o principal mecanismo atuante na evolução do maciço.

O pulso central, bem definido faciologicamente na morraria central do maciço, e com maior área de exposição, é representado por uma sucessão estratigráfica bem caracteri- zada e subdividida em duas sequências: uma inferior (fácies UMFc, MLGc e MLGc-C), que ocupa a sua porção basal, com predominância de cumulatos máficos e tendo olivina e clinopiroxênio como fases cumulus; e uma superior (GBPf e GBEq), que aflora nas regiões topograficamente mais elevadas, com maior abundância em rochas porfiríticas e equigranulares. Estas não mostram caráter cumulático e são mais evoluídas e ricas em componentes félsicos.

As rochas ultramáficas (UMFc) da região nordeste, bem como as melagábricas da porção sul da área principal parecem estar condicionadas a lineamentos estruturais, correspondentes na maioria dos casos às zonas de drenagem do maciço e sugerindo a ação do tectonismo (falhamentos) após a sua colocação.

Esse condicionamento estrutural possibilita a separação das porções oeste e sul da área principal das rochas da morraria central. A reconstrução da sucessão estratigráfica para a porção oeste do maciço indica a sua semelhança com a da sequência principal, mantido o mesmo padrão de distribuição com rochas mais máficas na base e mais evoluídas e félsicas no topo, não sendo, porém, possível uma subdivisão tão detalhada de fácies. Ressalte-se, ainda, que as rochas da porção noroeste, as mais evoluídas na sucessão, são bandadas nas áreas próximas ao contato com a encaixante. A mesma situação está presente no extremo SSE da área de exposição principal do maciço, onde rochas bandadas, mais evoluídas que os cumulatos máficos que as circundam, ocorrem associadas à região de contato com o embasamento. Esta associação de litotipos pode representar variações do pulso central, separadas unicamente pela ação de falhamentos, ou representar um pulso magmático isolado daquele da região central que, embora possuindo uma sequência inferior semelhante, evoluiu na sua sequência superior para rochas bandadas.

Admitida a primeira hipótese, as rochas evoluídas descritas nas regiões SSE e NW como fácies GB-Bnd deveriam estar posicionadas estratigraficamente com as rochas de topo da sequência do pulso central, com as ocorrências bandadas mais confinadas às zonas de contato com o embasamento granítico, onde correntes de convecção poderiam atuar de forma mais significativa.

Tabela 2. Idades K/Ar para diferentes litotipos do maciço Ponte Nova.

\begin{tabular}{|c|c|c|c|c|c|c|}
\hline Fácies & Amostra & $\begin{array}{c}\text { Material } \\
\text { (rocha - mineral) }\end{array}$ & $\% \mathrm{~K}$ & $A r_{\operatorname{Rad}}^{40}\left({ }^{*} 10^{-6}\right)(\mathrm{cc} T \mathrm{TP} / \mathrm{g})$ & $\begin{array}{c}\mathrm{Ar}^{40}{ }_{\mathrm{Atm}} \\
(\%)\end{array}$ & $\begin{array}{c}\text { Idade (Erro) } \\
(\mathrm{Ma})\end{array}$ \\
\hline $\mathrm{MLGc}$ & rga-58B & ol. melagabro cumul. - biotita & 6,37 & 22,73 & 25,56 & $89,6(2,6)$ \\
\hline GBPf & rga-83 & melamonzogabro c/nef. -biotita & 6,76 & 23,33 & 34,06 & $86,7(3,0)$ \\
\hline GB-Sul & rga-26 & melamonzodiorito c/nef. - biotita & 5,82 & 20,26 & 38,10 & $87,6(3,6)$ \\
\hline MZ-Sul & rga-18D & monzonito c/ nef. - biotita & 5,97 & 20,62 & 24,18 & $86,8(3,1)$ \\
\hline Gb-PL & rga-165a & nef. monzodiorito - biotita & 5,15 & 17,78 & 27,53 & $86,8(2,9)$ \\
\hline
\end{tabular}


A fácies rocha de matriz fina (GBMf), interpretada como a representante mais próxima a uma fácies de borda (ou chilled margin) encontrada no maciço, com rochas cumuláticas associadas, poderia estar posicionada na sequência estratigráfica principal com a sequência inferior, cumulática, ou estar associada unicamente à região sul e oeste da área principal, uma vez considerada como um pulso magmático isolado.

As rochas gabroides da área de exposição a sul (GBSul), separadas da intrusão principal por faixa de rochas do embasamento granítico, possuem características muito similares às das rochas porfiríticas e equigranulares (GBPf e GBEq) do pulso central. Além disso, estão topograficamente posicionadas em cotas semelhantes. Assim, poderiam ser consideradas como uma continuidade do pulso central, relacionada à sequência superior, ou, então, poderiam ser vistas como representativas de um pulso magmático isolado da área principal, mais evoluído. As rochas monzoníticas (MZ-Sul) comuns a essa ocorrência representariam as variedades mais evoluídas do pulso central, estando em nível topográfico superior ao anterior. Mas também não pode ser descartada a possibilidade de elas representarem um pulso magmático ainda mais evoluído que o do GB-Sul.

A fácies minério (ICPs e MTs) presente no morro com maior altitude topográfica do maciço, associado à morraria central, está representada por afloramentos únicos e restritos de ilmenita clinopiroxenitos sulfetados e magnetititos. Os ilmenita clinopiroxenitos sulfetados possuem ainda enclaves gábricos, alongados e achatados segundo a mesma direção de compactação dos cristais cumuláticos de clinopiroxênio, de composição semelhante aos GBEq, indicando uma possível interação entre magmas.

Essa situação, que também é comum a intrusões acamadadas, tais como camadas cromitíferas, camadas ricas em sulfetos, camadas de magnetititos, tem como explicação mais aceita a proposição de Irvine (1977), que afirma que a composição de um magma que está parcialmente diferenciado, pode ser deslocada para o campo de estabilidade de uma determinada fase mineralógica se misturada a um magma mais primitivo durante o reabastecimento da câmara magmática. Assim, o influxo de novo magma (possivelmente com a mesma composição do líquido inicial do pulso central) interagindo com líquido residual fracionado daria origem a um magma híbrido. Esse processo implica no deslocamento do líquido de sua linha cotética de cristalização em direção ao campo de estabilidade de alguma fase, resultando em uma rocha supersaturada em uma ou mais fases.

Dessa forma, é possível que essa fácies represente uma região de mistura entre as rochas mais evoluídas do pulso central e um novo pulso de composição mais primitiva, justificado pela elevada concentração de clinopiroxênio. A interação entre esses magmas poderia ter levado à saturação em fases opacas, como magnetita, ilmenita e, subordinadamente, sulfetos.

Endossando a ideia é a presença de enclaves com a mesma composição mineralógica e litológica, porém, de granulação mais fina, que os ilmenita clinopiroxenitos sulfetados hospedeiros. Esses enclaves encontram-se também alongados e achatados segundo a mesma orientação dos cristais cumulus da rocha hospedeira. Tal fato sugere a existência de mais de uma injeção de material com a mesma composição, o que corrobora ainda mais a hipótese de um outro pulso magmático. Por outro lado, os poucos afloramentos nessa região do maciço e o estado de alteração pronunciado da maioria dos afloramentos impedem que sejam feitas maiores considerações sobre a extensão lateral dessa fácies híbrida.

As rochas da fácies Koa, também com ocorrência limitada a condicionante geomorfológico bem caracterizado e extensão superficial restrita, apresentam características texturais e modais pouco usuais, sendo classificadas modalmente como kaersutita-óxido-apatita clinopiroxenitos. Sua formação parece estar associada principalmente a estágios pós-cumuláticos de cristalização, por uma ação efetiva de fluidos ricos em voláteis interagindo com cumulatos previamente formados.

A representação estratigráfica das rochas da sequência principal do maciço Ponte Nova e das seções e fácies correlacionáveis é mostrada na Figura 6.

Essa proposição de estratigrafia é indicativa de um pulso magmático com variações evolutivas em relação à sequência da morraria central do maciço ou, ainda, pode ser representativa de pelo menos três pulsos isolados. Considerando as complexidades comuns às câmaras magmáticas ambas as possibilidades são admitidas. Como sequência de topo para as rochas cumuláticas da morraria central tem-se a ocorrência (acima de GBEq) de pequenos blocos indicativos de acumulação de plagioclásio, que podem estar relacionados com a flutuação (ou flotação), por diferença de densidade, de cristais formados precocemente dentro da câmara magmática, e acumulados nas porções superiores. Feições como essas estão presentes em exemplos típicos de intrusões acamadadas, como Skaergaard e Rhum (Wager e Brown, 1968; McBirney, 1995). No caso de Ponte Nova, essas variedades, que estão pouco preservadas e possuem ocorrência restrita, talvez possam representar um volume ainda maior, porém, a ação intempérica dificulta as observações.

Outros pulsos magmáticos posteriores às sequências acima referidas são também reconhecidos, além de agrupados em função das suas próprias feições geomorfológicas e petrográficas. Este é o caso do pulso Norte (Gb-PN), 


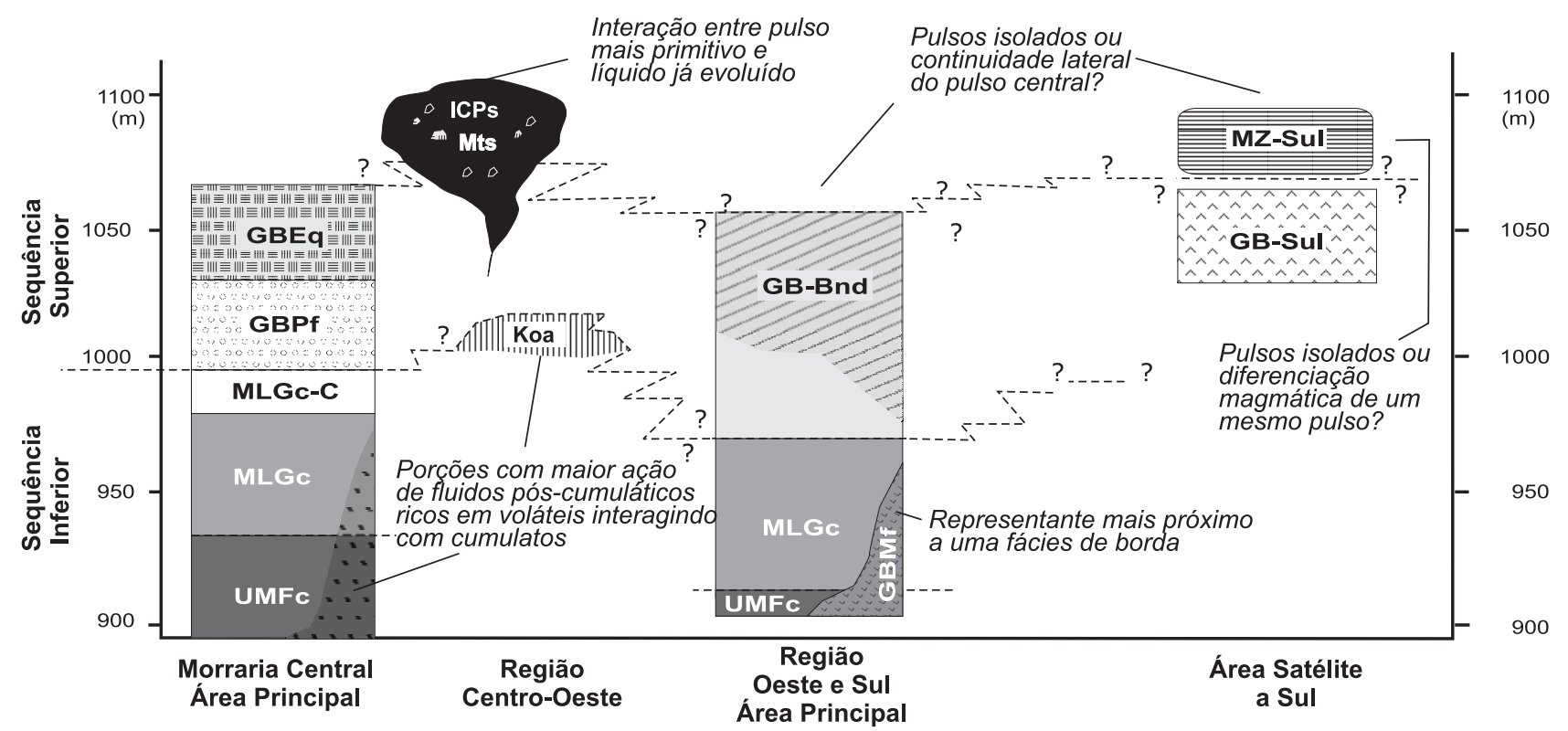

Figura 6. Seções estratigráficas propostas para as principais regiões do maciço Ponte Nova, e suas possíveis correlações.

com forma bem definida, subcircular, que mostra predominância de rochas melagábricas inequigranulares e, também, do pulso leste (Gb-PL), representado por rochas mais evoluídas, dominantemente porfiríticas, que contêm maior concentração de nefelina. Mesmo esses pulsos apresentam alguma evolução estratigráfica vertical, com variação, ainda que limitada, no índice máfico. As rochas mais ricas em clinopiroxênio e olivina estão associadas às bases dos morrotes, enquanto as mais feldspáticas ao topo.

É difícil definir o posicionamento estratigráfico desses dois pulsos, ambos posteriores ao pulso central, uma vez que eles não apresentam contatos entre si e, igualmente, pelo fato de suas rochas se situarem muito distantes umas das outras. De sorte que a ordem desses eventos deve ser entendida apenas como hipotética.

Essas relações estratigráficas observadas no âmbito geral do maciço, que indicam maior riqueza em constituintes máficos de formação inicial na base da câmara e aumento da concentração das fases félsicas nas sequências próximas ao topo, sugerem uma acumulação originada por segregação gravitacional, sendo os minerais separados por diferenças de densidade à medida que se processava a cristalização. Essa acumulação pode ter provocado o aprisionamento de líquidos residuais que posteriormente formaram os intercumulus e, nesse sentido, a ocorrência de bolsões dominantemente félsicos de dimensões centimétricas parece confirmar essa ação. Em algumas locais do maciço há também evidências da migração dos líquidos intercumulus, quer modificando a textura dos cumulatos previamente formados (texturas de corrosão) quer dan- do origem às vênulas félsicas injetadas por mecanismo do tipo filter pressing.

Ainda que localmente, a ocorrência de rochas bandadas associadas às bordas NW e SSE do maciço, próximas ao contato com o embasamento granítico, parece sugestiva da ação de correntes de convecção como fator responsável pelo processo acumulativo. No caso específico, o gradiente de temperatura entre o magma e a encaixante poderia gerar correntes de convecção locais permitindo a cristalização das bandas.

Posteriormente aos pulsos anteriormente descritos, conforme indicado pelos fragmentos líticos presentes, deu-se a formação da brecha magmática.

Diques máficos e félsicos interceptam as rochas do maciço. Os diques máficos, que são a grande maioria, quando in situ possuem posicionamento estrutural em direção ortogonal à colocação dos diques lamprofíricos de distribuição mais regional que cortam o embasamento. Além disso, com base na composição mineralógica, nota-se a tendência dos diques do maciço de serem mais evoluídos (menos olivina e mais plagioclásio) e menos insaturados em sílica (menos nefelina) que os diques regionais, sendo, no entanto, difícil até o momento estabelecer algum tipo de correlação temporal e genética entre eles.

\section{Contexto geodinâmico}

Uma das explicações fornecidas na literatura para a fonte do magmatismo alcalino Mesozoico-Cenozoico na parte sul do Brasil está ligada à existência de anomalias 
quentes do manto, que ocorrem na forma de hot spots ou plumas. Segundo Gibson et al. (1995) e Thompson et al. (1998), a pluma de Trindade, cujo impacto ao norte da Bacia do Paraná teria se dado entre 90 e 80 Ma e que atualmente se localiza sob a ilha de Trindade, foi o agente responsável, no continente, pela formação das províncias alcalinas de Poxoréu, Iporá e Alto Paranaíba (cf. subdivisão de Almeida, 1983). Nesse contexto, as ocorrências associadas ao Lineamento Magmático de Cabo Frio e ao setor norte da Província Serra do Mar (Riccomini, Velázquez, Gomes, 2005) seriam representativas da movimentação continental sob essa pluma, num intervalo entre 80 e $55 \mathrm{Ma}$ (Thompson et al., 1998).

Contudo, os dados geocronológicos obtidos para toda a porção norte da Província Serra do Mar estão confinados a um intervalo de idades entre 90 e $80 \mathrm{Ma}$. Para as ocorrências costeiras, os resultados disponibilizados por diferentes metodologias (K-Ar, Ar-Ar e $\mathrm{Rb}-\mathrm{Sr}$ ) indicam idades de 90 - 80 Ma para as ilhas de Vitória (Motoki, 1986), 86,5 Ma para Monte de Trigo (Enrich, Ruberti, Gomes, 2009), 84 - 81 Ma para São Sebastião (Bellieni et al., 1990; Montes-Lauar et al., 1995) e 81 - 79 Ma para Búzios (Alves, 1996). Para o maciço interiorano de Ponte Nova, as novas datações K-Ar obtidas indicam uma idade média de 87,6 Ma. Esse conjunto de valores não é compatível com o modelo evolutivo da pluma de Trindade (cf. Thompson et al., 1998), uma vez que eles se colocam no mesmo cronogrupo proposto para o possível impacto da pluma no continente. Além disso, a distância estimada de aproximadamente $700 \mathrm{~km}$ entre o maciço e o provável eixo da pluma, separados por uma espessa litosfera associada ao Craton São Francisco, parece não suportar essa influência em sua gênese. O mesmo se dá para as demais ocorrências costeiras da província, ainda mais distantes do eixo principal. Dessa forma, a aplicação do modelo da pluma de Trindade poderia ser eventualmente restringida às ocorrências do lineamento de Cabo Frio, estando, portanto, além dos objetivos deste trabalho.

Por outro lado, modelos envolvendo componentes essencialmente litosféricos têm sido também propostos na literatura (e.g., Smith e Lewis, 1999; Comin-Chiaramonti et al., 2005). Esses autores admitem a reativação de antigas zonas de falhamentos, com alívio de pressão por processos de rifteamento ligados à movimentação da Placa SulAmericana, associadas a fontes mantélicas ricas em voláteis, que promoveriam o abaixamento da temperatura do solidus mantélico.

Nesse sentido, como salientado por Riccomini, Velázquez e Gomes (2005), o magmatismo alcalino das partes central e sudeste da Plataforma Sul-Americana, com idade variável do Mesozoico ao Cenozoico, mostra evidente controle tectônico por descontinuidades crustais e uma li- gação evolutiva com as principais bacias sedimentares da região. Os pulsos magmáticos encontram-se associados às principais zonas de fraqueza de alcance regional, geralmente zonas de falha situadas ao longo das bordas das bacias sedimentares. No caso do setor norte da Província Serra do Mar, ao qual o maciço Ponte Nova faz parte, seu desenvolvimento está ligado às bordas da Bacia de Santos, onde zonas de cisalhamento proterozoicas ao lado de outras zonas de fraqueza tiveram sua reativação facilitada, sendo, ainda, o Cretáceo Superior um dos principais períodos relacionados à elevação da Serra do Mar.

Quanto ao enriquecimento em voláteis do manto, fluidos ou fusões ligados aos processos neoproterozoicos de subducção associados à evolução das principais faixas móveis da Plataforma Sul-Americana (e.g., Heilbron et al., 2004), ou mesmo pequenos volumes de fusão astenosférica, ou mesmo ambos os mecanismos, podem ter causado a venulação do manto litosférico sobrejacente em diferentes profundidades (Ruberti, Gomes, CominChiaramonti, 2005).

De forma complementar, uma elevação da temperatura do manto litosférico pode estar associada a anomalias térmicas mantélicas de longa duração, reveladas por anomalias de geoide (Ernesto et al., 2002), ou por uma ação termal residual da pluma de Tristão da Cunha, do Cretáceo Inferior (Vandecar, James, Assumpção, 1995).

Assim, é possível que a soma dessas variáveis, ligadas em maior ou menor proporção principalmente a fenômenos litosféricos, tenha sido o agente responsável pela geração do magmatismo alcalino do maciço Ponte Nova e das demais ocorrências da Província Serra do Mar.

\section{AGRADECIMENTOS}

Esta pesquisa foi financiada pela FAPESP (Procs. 03/00626-5 e 01/10714-3). Os autores agradecem também ao Prof. Dr. Francisco Rubens Alves pelo auxílio em trabalhos de campo e fornecimento das amostras de seus trabalhos anteriores na região. Também de relevante importância foram os comentários e sugestões oferecidos pelos relatores desta revista.

\section{REFERÊNCIAS BIBLIOGRÁFICAS}

ALMEIDA, F. F. M. Relações tectônicas das rochas alcalinas mesozóicas da região meridional da plataforma sul-americana. Revista Brasileira de Geociências, v. 13, p. 139-158, 1983.

ALMEIDA, F. F. M. Distribuição regional e relações tectônicas do magmatismo pós-paleozóico no Brasil. Revista Brasileira de Geociências, v. 16, p. 325-349, 1986. 
ALMEIDA, F. F. M.; AMARAL, G.; CORDANI, U. G.; KAWASHITA, K. The Precambrian evolution of the South American cratonic margin south of the Amazon River. In: NAIRN, A. E. M.; STEHLI, F. G. The ocean basins and margins. New York: Plenum Publ., 1973. v. 1, p. 411-446.

ALMEIDA, F. F. M.; HASUI, Y.; PONÇANO, W. L.; DANTAS, A. S. L.; CARNEIRO, C. D. R.; MELO, M. S.; BISTRICHI, C. A. Mapa geológico do Estado de São Paulo. São Paulo: IPT, 1981. 126 p. Escala 1:500.000.

ALVES, F. R. Nota sobre o corpo gabróide de Sapucaí Mirim, SP/MG. In: CONGRESSO BRASILEIRO DE GEOLOGIA, 30., 1978., Recife. Resumo dos Trabalhos... Recife: SBG, 1978, p. 95.

ALVES, F. R. Contribuição ao conhecimento geológico e petrológico das rochas alcalinas da Ilha dos Búzios, SP. 1996. 274 f. Tese (Doutorado) - Instituto de Geociências, Universidade de São Paulo, São Paulo, 1996.

ALVES, F. R.; RUBERTI, E.; VLACH, S. R. F. Magmatismo meso-cenozóico da região da Serra da Mantiqueira, SP/MG. Boletim IG-USP. Publicação Especial, v. 12, p. 7-9, 1992.

AMARAL, G.; CORDANI, U. G.; KAWASHITA, K.; REYNOLDS, J. H. Potassium-Argon dates of basaltic rocks from southern Brazil. Geochimica et Cosmochimica Acta, v. 30, p. 159-189, 1966.

AUGUSTO, T. Petrografia e quimismo mineral de rochas gábricas e sieníticas do maciço de São Sebastião, Ilha de São Sebastião, SP. 2003. 50 f. Trabalho de Formatura (Geociências) - Instituto de Geociências, Universidade de São Paulo, São Paulo, 2003.

AZZONE, R. G. Petrogênese do maciço alcalino máfico-ultramáfico Ponte Nova (SP-MG). 2008. 240 f. Tese (Doutorado) - Instituto de Geociências, Universidade de São Paulo, São Paulo, 2008.

BELLIENI, G.; MONTES LAUAR, C. R.; DE MIN, A.; PICCRILlO, E. M.; CAVAZZINI, G.; MELFI, A. J.; PACCA, I. G. Early and late cretaceous magmatism from São Sebastião Island (SE - Brazil): geochemistry and petrology. Geochimica Brasiliensis, v. 4, p. 59-83, 1990.

CAVAlCANTE, J. C.; CUNHA, H. C. S.; CHIERAGATI, L. A.; KAEFER, L. Q.; ROCHA, J. M.; DAITX, E. C.; COUTINHO, M. G. N.; YAMAMOTO, K; DRUMOND,
J. B. V.; ROSA, D. B.; RAMALHO, R. Projeto Sapucaí: relatório final de Geologia. Brasília: DNPM, 1979. v. 2, 299 p. (Série Geologia 4).

COMIN-CHIARAMONTI,P.; GOMES, C.B.; MARQUES, L. S.; CENSI, P.; RUBERTI, E.; ANTONINI, P. Carbonatites from southeastern Brazil: geochemistry, O-C, Sr-Nd$\mathrm{Pb}$ isotopes and relationships with the magmatism from the Paraná-Angola-Namibia Province. In: COMIN-CHIARAMONTI, P.; GOMES, C. B. ( Ed.s). Mesozoic to Cenozoic alkaline magmatism in the Brazilian Platform. São Paulo: EDUSP-FAPESP, 2005. p. 657-688.

ENRICH, G. E. R., RUBERTI. E.; GOMES, C. B. Geology and geochronology of Monte de Trigo Island Alkaline Suite, southeastern Brazil. Revista Brasileira de Geociências, 2009. No prelo.

ERNESTO, M.; MARQUES, L. S.; PICCIRILLO, E. M.; MOLINA, E. C.; USSAMI, N.; COMINCHIARAMONTI, P.; BELLIENI, G. Paraná Magmatic Province-Tristan da Cunha plume system: fixed versus mobile plume, petrogenetic considerations and alternative heat sources. Journal of Volcanic Geothermal Research, v. 118, p. 15-36, 2002.

FREITAS, R. O. Geologia e petrologia da Ilha de São Sebastião. Boletim da Faculdade de Filosofia, Ciências e Letras da Universidade de São Paulo. Geologia, v. 85, n. 3, p. 1-244, 1947 .

GARDA, G. M.; CHIERAGATTI, L. A. As rochas máficasultramáficas do complexo de Ponte Nova, MG-SP. In: SIMPÓSIO SOBRE A GEOLOGIA DO SUDESTE, 5., 1997, Penedo- RJ. Anais... Itatiaia: SBG, 1997. p. 29-30.

GIBSON, S. A.; THOMPSON, R. N.; LEONARDOS, O. H.; DICKIN, A. P.; MITCHELL, J. G. The Late Cretaceus Impact of the Trindade mantle plume. Evidence from large-volume mafic, potassic magmatism in SE, Brazil. Journal of Petrology, v. 36, p. 189-230, 1995.

GOMES, C. B.; COMIN-CHIARAMONTI, P. An introduction to the alkaline and alkaline-carbonatitic magmatism in and around the Paraná-Basin. In: COMINCHIARAMONTI, P.; GOMES, C. B. (Eds.) Mesozoic to Cenozoic alkaline magmatism in the Brazilian Platform. São Paulo: EDUSP-FAPESP, 2005. p. 21-30.

HAMA, M.; ALGARTE, J. P.; KAEFER, L. Q.; ARTUR, A. C. Idade $\mathrm{Rb} / \mathrm{Sr}$ na região sul de Minas Gerais e leste de São Paulo. In: SIMPÓSIO REGIONAL DE GEOLO- 
GIA, 2., 1979, Rio Claro. Atas... Rio Claro: SBG, 1979, v. 1, p. $71-86$.

HEILBRON, M.; PEDROSA-SOARES, A C.; CAMPOS NETO, M. C.; SILVA, L. C.; TROUW, R. A. J.; JANASI, V. A. Província Mantiqueira. In: MANTESSONETO, V.; BARTORELLI, A.; CARNEIRO, C. D. R.; BRITO-NEVES, B. B. Geologia do Continente Sul-Americano: evolução da obra de Fernando Flávio Marques de Almeida. São Paulo: Beca Produções Culturais Ltda, 2004. p. 203-234.

HUNTER, R. H. Texture development in cumulate rocks. In: CAWTHORN, R. G. (Ed.) Layered intrusions. Amsterdam; New York: Elsevier, 1996. p. 77-101.

IRVINE, T. N. Origin of chromitite layers in the Muskox intrusion and other stratiform intrusions. Geology, v. 5, p. $273-277,1977$.

IRVINE, T. N. Terminology for layered intrusions. Journal of Petrology, v. 23, p. 127-162, 1982.

LE MAITRE, R. W. Igneous rocks: a classification and glossary of terms. $2^{\text {nd }}$ ed. Cambridge: Cambridge University Press, 2002. 236 p.

LIMA, G. A. Gabros estratiformes da região norte da Ilha de São Sebastião, SP. 2001. 170 f. Dissertação (Mestrado) - Instituto de Geociências, Universidade de São Paulo, São Paulo, 2001.

MACHADO, N.; VALLADARES, C.; HEILBRON, M.; VALERIANO, C. U-Pb geochronology of the central Ribeira belt (Brazil) and implications for the evolution of the Brazilian Orogeny. Precambrian Research, v. 79, p. $347-361,1996$.

McBIRNEY, A. R Mechanisms of differentiation in the Skaergaard Intrusion. Journal of Geological Society of London, v. 152, p. 421-435, 1995.

MELCHER, G. C.; MELCHER, B. A. Novas ocorrências de rochas alcalinas no estado de São Paulo. In: CONGRESSO BRASILEIRO DE GEOLOGIA, 26., 1972, Belém. Resumo das Comunicações... Belém: SBG, 1972. v. 1, p. 216-217.

MINIOLLI, B. Determinações potássio-argônio em rochas localizadas no litoral norte do Estado de São Paulo. Anais da Academia Brasileira de Ciências, v. 43, p. 443-448, 1971.
MONTES-LAUAR, C. R.; PACCA, I. G.; MELFI, A. J.; KAWASHITA, K. Late Cretaceous alkaline complexes, southeastern Brazil: paleomagnetism and geochronology. Earth Planetary Science Letters, v. 134, p. 425-440, 1995.

MORBIDELLI, L.; GOMES, C. B.; BECCALUVA, L.; BROTZU, P.; CONTE, A. M.; RUBERTI, E.; TRAVERSA, G. Mineralogical, petrological and geochemical aspects of alkaline and alkaline-carbonatite associations from Brazil. Earth Science Reviews, v. 39, p. 135-168, 1995.

MOTOKI, A. Geologia e petrologia do complexo alcalino da Ilha de Vitória, SP. 1986. 245 f. Tese (Doutorado)Instituto de Geociências, Universidade de São Paulo, São Paulo, 1986.

RICCOMINI, C.; VELÁZQUEZ, V. F.; GOMES, C. B. Tectonic controls of the Mesozoic and Cenozoic alkaline magmatism in the central-southeastern Brazilian Platform. In: COMIN-CHIARAMONTI, P.; GOMES, C. B. (Eds.). Mesozoic to Cenozoic alkaline magmatism in the Brazilian Platform. São Paulo: EDUSP-FAPESP, 2005. p. 31-56.

ROCK, N. M. S. Lamprophyres. Blackie-Van Nostand Reinhold, 1991. 285 p.

RUBERTI, E.; ALVES, F.R.; KAWASHITA, K.; VLACH, S.R.F. Geologia e petrologia do maciço máfico-ultramáfico de Ponte Nova e diques associados. 1993. (Relatório - Projeto FAPESP 90/4848-0).

RUBERTI,E.;GOMES,C.B.;COMIN-CHIARAMONTI, P. The alkaline magmatism from the Ponta Grossa Arch. In: COMIN-CHIARAMONTI, P.; GOMES, C. B. (Eds.). Mesozoic to Cenozoic alkaline magmatism in the Brazilian Platform.. São Paulo: EDUSP-FAPESP, 2005. p. 473-522.

SANTORO, E. Evolução geológica do Pré-Cambriano da região de Santo Antônio do Pinhal, SP: importância tectônica das zonas de cisalhamento. 1998. 153 f. Tese (Doutorado) - Instituto de Geociências, Universidade de São Paulo, São Paulo, 1998.

SMITH, A. F.; LEWIS, C. The planet beyond the plume hypotesis. Earth Science Reviews, v. 48, p. 135-182, 1999.

SONOKI, I. K.; GARDA, G. M. Idades K-Ar de rochas alcalinas do Brasil Meridional e Paraguai Oriental: compilação e adaptação às novas constantes de decaimento. Boletim IG-USP, v. 19, p. 63-85, 1988. 
STEIGER, R. H.; JAGER, E. Subcomission on geochronology: convention on the use of decay constants in geo and cosmochronology. Earth Planetary Science Letters, v. 36, p. 359-362, 1977.

THOMPSON, R. N.; GIBSON, S. A.; MITCHELL, J. G.; DICKIN, A. P.; LEONARDOS, O. H.; BROD, J. A.; GREENWOOD, J. C. Migrating Cretaceous-Eocene magmatism in the Serra do Mar Alkaline Province, SE Brasil: melts from the deflected Trindade mantle plume? Journal of Petrology, v. 39, p. 1493-1526, 1998.

ULBRICH, H. H. G. J.; GOMES, C. B. Alkaline rocks from Brazil. Earth Science Reviews, v. 17, p. 135-154, 1981.

VANDECAR, J. C.; JAMES, D. E.; ASSUMPÇÃO, M. Seismic evidence for a fossil mantle plume beneath South America and implications for plate driving forces. Nature, v. 378, p. 25-31, 1995.

WAGER, L. R.; BROWN, G. M. Layered igneous rocks. San Francisco: W. H. Freeman, 1968. 588 p.

WAGER, L. R.; BROWN, G. M.; WADSWORTH, W. J. Types of igneous cumulates. Journal of Petrology, v. 1, p. 73-85, 1960.

WOOLLEY, A. R.; BERGMAN, S. C.; EDGAR, A. D.; LE BAS, M. J.; MITCHELL, R. H.; ROCK, N. M. S.; SCOTT SMITH, B. H. Classification of lamprophyres, lamproites, kimberlites, and the kalsilitic, melilitic, and leucitic rocks. Canadian Mineralogist, v. 34, p. 175-186, 1996. 